\title{
R\&D and innovation policy in the Western Balkans: are there additionality effects?
}

\begin{abstract}
This article examines three types of additionality - input, output and behavioural - in a crosscountry framework. Besides conducting a systemic evaluation, which is scarce even in developed economies, this is among the first studies to investigate the effectiveness of $R \& D$ and innovation policy in transition economies. We estimate treatment effects for small and medium-sized firms (SMEs) in six Western Balkan countries. Empirical findings from matching estimators indicate no input and output additionality, while we find evidence of behavioural additionality. These results highlight the importance of conducting a systemic evaluation of innovation public support. We discuss theoretical and policy implications stemming from our empirical findings.
\end{abstract}

Key words: R\&D support; SMEs; input, output and behavioural additionality

\section{Introduction}

Ever since Schumpeter's seminal work, the importance of R\&D and innovation for sustained economic growth and long-term competitiveness has been widely acknowledged among economic scholars as well as among entrepreneurs and policy makers. As a result, governments around the world have been allocating a wide range of public instruments to promoting R\&D. Government intervention is justified on the grounds of non-appropriability, non-divisibility and uncertainty that prevent firms from totally internalizing the benefits of $R \& D$ investment (Arrow, 1962) resulting in the level of private $R \& D$ investment below the socially optimal level (Spence, 1984).

However, policy interventions directed at innovation need to go beyond the solution to market failure to achieve successful innovation (Antonioli et al., 2014). Innovation is a complex process involving different actors and interactions and therefore has a "system" nature (Edquist, 2005). From a system perspective, standard innovation policies such as R\&D subsidies can be used to address system failures and enhance firms' innovation capabilities, competencies and interactions with external actors leading to behavioural additionality 
(Antonioli and Marzucchi, 2012). In line with an increasing demand for systemic evaluation, one recommendation is that the concept of additionality should be explored in an integrated approach (Magro and Wilson, 2013). To reflect this emerging practice, our first contribution in the area of innovation research is to assess all three types of additionality - input, output and behavioural in the Western Balkans (WB), thus adding to a small body of literature on government aid for innovation in transition countries. To date, there have been a number of firm level studies that found predominantly positive effects of government R\&D subsidies on firms' innovation performance (Dimos and Pugh, 2016). However, most of the studies in the literature are national level papers with few undertaking a cross country analysis (Crowley and McCann, 2018; Radicic et al., 2016; Szczygielski et al., 2017) on a set of countries that are far from technological leaders.

The innovation process in the Western Balkans is likely to be somewhat different to those in more developed economies because they are operating in different institutional, innovative and competitive environment (Schwab et al., 2017). Consequently, the important question is whether public support for innovation can help firms in the WBs move up the technology ladder given weak state capacity and corruption in the region. This may affect the effectiveness of public subsidies and programmes and result in "pick the winners" strategy to fund the firms which would engage in innovation regardless of subsidies (Radicic et al., 2016). Moreover, government bureaucrats have limited technological and business expertise in evaluating venture quality (Lerner, 2009). In addition, in countries with weak institutional framework and underdeveloped innovation ecosystems, such as WB countries, public financing may be insufficient to effectively correct market failures. While in developed countries the availability of venture capital may close the funding gap, venture capital funds in WB countries are still in their infancy.

With that in mind, our second contribution is to evaluate whether public support measures are effective in the case of SMEs. As argued by Herrera and Sanchez-Gonzales (2013), contemporary knowledge of the relationship between firm size and innovation policy is insufficient for policymakers to make informed decisions about policy design, stimulation of certain technologies or accumulation of knowledge. Although large firms have been regarded as main actors in the process of technological change and future growth, smaller firms are now viewed as agents of change bringing technological diversity which stimulates growth and evolution of industry (De Jong and Vermeulen, 2006).

In the Western Balkans, SMEs represent above $99 \%$ of total number of enterprises and employ more than $67 \%$ employees (OECD, 2018). Likewise, SMEs account for more than half 
of the total added value created, therefore, their capacity to innovate is essential for a country's success in a competitive global business environment. Our focus on SMEs fits within the objective to provide 'less and better' state aid (Moncada et al., 2010) and is in line 'with the flagship initiative 'Innovation Union,' established in the context of the 'Europe 2020' targets (EC-DG Research and Innovation, 2011). The aim of the policy is to encourage innovation activities of firms facing specific constraints. Moreover, the Small Business Act for Europe highlights the need to encourage collaboration to improve the transfer of knowledge between SMEs.

The remainder of this paper is structured in five sections. Section 2 draws on innovation literature to discuss the effects of $R \& D$ subsidies on input, output and behavioural additionality in SMEs, followed by the review of empirical studies. Section 3 provides a comparative perspective of $R \& D$ and innovation policies in the Western Balkans. Section 4 provides an overview of the matching estimators and data used in the study and specifies the empirical model. Section 5 discusses the results of the empirical analysis. Finally, section 6 concludes and provides policy recommendations.

\section{R\&D subsidies and additionality effects}

Government support for R\&D investment is based on two well-known arguments. The first is the public good problem associated with $R \& D$ investment in that it is both non-rivalrous and not (completely) excludable leading to a lower than the optimal social level of investment in research (Arrow, 1962; Nelson, 1959). Consequently, the appropriability of R\&D outputs is not perfect, which reduces the incentives to do $R \& D$ on the part of the private firms. The second is related to capital market imperfections that hamper firms' ability to raise external finance due to the information asymmetry between investors and borrowers. In essence, R\&D investments are associated with high risks and uncertainty, long time horizons and often involve multiple stages of development, thus investors cannot anticipate the value of such investments with confidence (Hall and Lerner, 2010).

In contrast to mainstream theories motivating public support for innovation, the evolutionary perspective posits that firms are embedded in a national network of institutions (Chaminade et al., 2018). From this perspective, innovation outcome is the result of learning processes and the quality and quantity of interactions between different institutions at all administrative levels (Gobble, 2014; Lundvall and Nielsen, 2007). Therefore, including 
evolutionary insights and systems perspectives on innovation enables more complete assessment of the impact of public measures on firms' innovative behaviour (Georghiou and Clarysse, 2006).

Direct subsidies that are the focus of this paper are among the most widely used and extensively studied policy instruments used to mitigate market failures. Their aim is to reduce the share of costs of $R \& D$ investments borne by private firms and consequently the amount of financing that needs to be raised. However, the positive effects of R\&D subsidies on innovation and technological progress may not realise as firms might undertake projects at the same scale even if no subsidies were granted. In that case, firms will simply substitute their own R\&D spending with public subsidies, leading to full or partial crowding out effects of private investment, under-mining the argument for "additional" effects of public aid. Since large firms have larger R\&D capacity they are more likely to apply for R\&D subsidies.

Potential reasons for crowding out are not only related to firm behaviour, but also with government agency selection procedures. Although policy makers have designed the eligibility criteria for public R\&D programs, the evaluation of technological and business potential may prove to be a difficult task. Further, funding agencies may favour innovation projects with high private returns or low risk or projects that were highly likely to succeed anyway (Wallsten, 2000). In case that government wants to maximise the returns of the subsidy program, they may well choose to finance only large firms. Their successful implementation might improve the image of the funding agency, but is not socially optimal, as it may crowd out other potentially successful investment that could have taken place. In the following subsections, we are going to shed more light on the potential relationship between R\&D subsidies and SMEs innovative behaviour.

\subsection{Input additionality in SMES}

It is well recognized that SMEs underinvest in $R \& D$ due to capital market imperfections as size appears to be correlated with the availability and stability of internally-generated funds (Schumpeter, 1942). Going beyond capital market imperfections, several other explanations have been put forward to explain lower propensity of SMEs to engage in innovative activities. Firstly, small firms are not able to spread the risks over a large number of R\&D projects and produce an output over which they can apply the results of their R\&D expenditures, both in terms of cost reduction (process innovation) and development of new products (Cohen and Klepper, 1996; Ortega-Argiles et al., 2009). Secondly, high variance in expected returns and 
very low probability of achieving a high pay-off reduces the incentives of SME to invest in $\mathrm{R} \& \mathrm{D}$ and makes it more unlikely that it will choose to finance through capital markets (Scherer and Harhoff, 2000). Thirdly, heterogeneity between SMEs also plays a role as firms differ in their competences (Garcia-Quevedo and Mas-Verdu, 2008) and entrepreneurial spirit (van Praag and Versloot, 2008). Given the limited resources, it is expected that SMEs will invest fewer resources in $R \& D$ and when they do, they will mostly focus on technological development activities that provide immediate solutions to the problem (Santoro and Chakrabarti, 2002) and generate knowledge that is close to the firm's technological domain and its market (Roper et al., 2004).

A traditional approach for assessing input additionality is based on estimating firms' own R\&D investment in the presence of subsidies. However, the longstanding question is whether firms complement or substitute subsidy for their own R\&D effort (Dimos and Pugh, 2016). Namely, receiving public support for innovation activities could induce firms to increase their innovation efforts, which is regarded as additionality (i.e. a complementary effect). In contrast, firms might substitute their private innovation investment with public funding, which is a crowding-out effect (Radicic et al., 2016). As previously discussed, the theory alone cannot be used to predict the size or the direction of the effect of R\&D subsidy on private R\&D. On the one hand, provision of public subsidies aims to mitigate market failures, but on the other hand their effectiveness may be reduced by self-interested selection procedures on the part of public bureaucracies and asymmetric information between public agencies and private firms. Therefore, the issue of additionality versus crowding out effects remains an empirical one (Dimos and Pugh, 2016).

Most of the empirical literature has been conducted in the context of developed countries and reported positive and significant, albeit small input additionality in the case of SMEs (e.g. Alecke et al., 2012; Czarnitzki and Hottenrott, 2011; Radicic et al., 2016). In recent meta-analysis, Dimos and Pugh (2016) tend to reject full crowding-out effects but reveal no evidence of substantial additionality. Differentiating between R\&D expenditure on basic research, applied research and technological development activities, Herrera and SanchezGonzales (2013) found that SMEs focus mostly on the latter two when requesting public R\&D subsidies. Moreover, Czarnitzki and Delanote (2015) find the largest treatment effects both in terms of $R \& D$ expenditures and in terms of $R \& D$ employment for high-tech small young firms relative to low-tech young firms and non-independent counterparts.

Apart from increased $R \& D$ expenditure and $R \& D$ employment, it is expected that participation in public grants can induce positive changes in firms' R\&D-related behaviour. 
For example, through innovation firms can expand the base of codified and tacit knowledge and increase their technological performance (Hewitt-Dundas, 2006) and absorptive capacity (Radas et al., 2015). Public R\&D subsidies make it possible for firms to engage in new projects and accumulate new knowledge through experience and collaboration. Therefore, even in the absence of input additionality, the impact of subsidies may be positive to the extent that the potential substitutability of input and output additionalities with behavioural additionality is accounted for (Clarysse et al., 2009; Georghiou, 2002).

\subsection{Output additionality in SMEs}

Few studies attempt to analyse output additionality which is somewhat puzzling given that innovation output represent the ultimate aim of public R\&D subsidies. Most studies find positive effects of R\&D subsidies on output additionality when innovation output is measured in terms of patenting activities (Bronzini and Piselli, 2016; Czarnitzki and Hussingar, 2018). Focusing specifically on SMEs, Foreman-Peck (2013) find that public support increases the probability of introducing product or process innovations in manufacturing and service UK SMEs. Radicic et al. (2016) investigate SMEs in traditional manufacturing industries, and report that public support typically increases the probability of technological and nontechnological innovations and of their commercial success by around $15 \%$. Hottenrott and Lopes-Bento (2014) assess the effectiveness of direct financial support for R\&D in fostering innovation via its capacity in firstly promoting companies' input additionality in Flemish SMEs.

In comparison to other studies we focus on innovation outcome. Specifically, we use the dichotomy 'sale of products new for the firm' and 'sale of products new for the market'. This distinction has important implications for firms' innovation strategy and evaluation strategy of policy maker (Beck et al., 2015). In accordance with Kaufmann and Tödtling (2001), 'sale of products new for the firm' is associated with incremental innovations aimed at increasing the competitive position in the same market and ensuring their long-term survival and thus requires few resources and relatively simple collaboration relationships (Keizer and Halman, 2007). 'Sale of products new for the market' is associated with radical innovations focused on the value of the firm and the impact of the technology on the market. This type of innovation has the ability to shift the technology frontier of firms/sectors and enable firms to diversify their markets. Firms with strong emphasis on innovation and technology are more likely to engage in radical innovations associated with higher costs and a longer and 
unpredictable life cycle (Herrmann et al., 2006). Since investment in radical R\&D often entails high risk and uncertainty and firms are usually risk-averse, underinvestment in radical R\&D may be more pronounced. Therefore, it is expected that public support will be aimed at the type of investment where market imperfections are higher. However, in short and medium term, innovation output from less radical innovation projects may be favoured by both firms and policy makers (Beck et al., 2015).

Analysis of firm size and the degree of novelty of innovation output are scarce and inconclusive (Oke et al., 2007; Paulson et al., 2007). On one hand, it is argued that large firms have the advantage when it comes to incremental innovation due to their superior capacity and knowledge (Oke et al., 2007). On the other hand, Paulson et al. (2007) argue that SMEs have flexibility and speed when introducing innovations. In the case of radical innovation, it has been argued that financial returns are greater for large firms give their market reach (Paulson et al., 2007). Alternatively, SMEs are sometimes founded on a radical idea that may be able to renew an entire industrial sector (Koellinger 2008). In addition, Kassicieh et al. (2002) associate small firms in certain sectors with the commercialization of disruptive technologies that generate discontinuous innovations.

In general, the literature has not dealt with analysing how innovation policy affects economic returns to innovation with respect to the degree of novelty of innovation output of SMEs in the context of developing countries. It still remains unclear whether public R\&D subsidies are productive and whether their impact is higher when market failures are more pronounced.

\subsection{Behavioural additionality in SMEs}

Behavioural additionality refers to knowledge acquisition and developments of learning and R\&D management capabilities, competencies and strategies, including cooperation strategies (Antonioli and Marzucchi, 2012). Although the concept of behavioural additionality has been used with different interpretations and dimensions (Gök and Edler, 2010; OECD, 2006), we choose as relevant that of cooperative relations with other partners. This is in line with the evolutionary framework, which argues that overcoming the limited cognitive capacity of agents is the main rationale of an innovation policy (Bach and Matt, 2005).

$\mathrm{R} \& \mathrm{D}$ cooperation has emerged as an appropriate measure both for its theoretical underpinnings stemming from the resource-based theory of the firm (Wernerfelt, 1984) and its empirical relevance (Busom and Fernandez-Ribas 2008; Cerulli et al., 2016; Clarysee et al., 
2009). According to the resource-based view, firms seek access to complementary or similar resources (Arranz and de Arroyabe, 2008). Recently there has been a systematic and fundamental change in the way how firms undertake innovative activities. Scholars studying social capital have emphasised the role of networks and linkages with other social entities as a mean to access various resources that would be beyond firms' reach if they were to act in isolation (Elfring and Hulsink, 2003). The importance of external ideas, knowledge and networks has also been emphasised in the open innovation model (Chesbrough, 2003) where SMEs are expected to engage in technology collaboration networks to search for and access external resources required for innovation. From the perspective of the wider innovation ecosystem, the greater the technological diversity between firms, the greater the opportunities to cooperate to innovate more complex products that are harder to imitate and thus a source of individual competitive advantage (Song, 2016).

Research collaborations are an important channel for both unintended knowledge spillovers and deliberated forms of knowledge access (D'Este et al., 2013). The literature identifies many advantages of cooperation that help SMEs to overcome the liability of smallness and increase their ability to innovate. First, cooperation enables SMEs to increase their competitiveness by pooling, integrating and combining their resources with external partners (Miotti and Sachwald, 2003) and enables them to share costs and risks related to the development of new technology (Ferreira et al., 2015; Hagedoorn, 2002). Inter-firm R\&D alliances are seen as opportunity to gain access to complementary technological resources which can speed up the innovation process, improve market access and contribute to economies of scale (Cassiman and Veugelers, 2002; López, 2008). Second, cooperation in innovation activities allow firms to internalize R\&D spillovers, providing benefits not only to the innovating firm but also to other partners involved (Becker and Dietz, 2004) and these spillover overs tend to larger for small firms (Chun and Mun, 2012).

With that in mind, geographical proximity is frequently claimed to be beneficial for a successful collaboration and exchange of tacit knowledge. However, the importance of geographical proximity has been questioned, the main argument being that "simple" colocation is neither a prerequisite nor a sufficient condition" (Boschma 2005, p.71). It is argued that institutional, cognitive, and social proximity also matter. For example, cooperation between academia and industry is characterized by lower institutional and cognitive proximity which can bring about novel solutions and variety in both firms' internal routines and lead to more radical forms of innovation (Kaufmann and Tödtling, 2001). 
However, problems typically arise due to increased exploitation costs in terms of processing, understanding and absorbing external knowledge (Noooteboom, 2000) and due to differences in research goals and incentive structures (Ponds et al., 2007). The more partners involved in the network, the more complex the transfer of information. Opportunistic behaviour by partners may have negative effects on cooperation as they may lack incentives to reveal their internal inventions. This creates the climate of mistrust and leads to a reduced effort in cooperative partnerships when cooperating firms do not clearly specify which partner will be assigned exclusive property rights (Dhont-Peltrault and Pfister, 2011). Further, searching for an appropriate partner and building up trust, as well as the costs related to contracting and enforcement between the involved partners are associated with transaction costs (Hottenrott and Lopes-Bento, 2014). These costs are particularly important for SMEs as they often lack the critical factors for successful cooperation, such as partnership governance, managerial skills and experience necessary for developing and maintaining successful cooperative ties (Radicic et al., 2018). To overcome the complexities of these collaborations and to enforce a mutual trust, geographical proximity may still play a role in establishing successful partnerships between organizations with different institutional backgrounds.

The previous arguments have important implications on firms' cooperative decisions. As long as partners' proximity in one of the dimensions compensate for distance in another, it is expected that propensity to cooperate would increase. Cooperation costs are expected to increase with distance and therefore a simple administration of an R\&D subsidy can induce firms to engage in cooperation and attenuate the costs implied by different gaps in the proximity between firms and other institutions (Marzucchi et al., 2015).

The literature also identifies several channels that condition firms' preferences regarding the type of cooperative partner. $R \& D$ cooperation with external partners such as customers, suppliers and private or public knowledge providers is related to a variety of advantages. The main reason for vertical cooperation associated with suppliers and customers is that firms gain access to complementary resources and capabilities (Un et al., 2010). For example, cooperation with suppliers can facilitate knowledge sharing on cost reduction technologies and help firms to improve their current products or introduce new products (Belderbos et al. 2004). Cooperation with customers can facilitate market acceptance and commercialization of new products. In addition, customers have been found to be instrumental when new products require adaptations for their usage due to their complexity or novelty (Tether, 2002). 
Cooperation with competitors is of great value for a firm since rivals often have similar needs in the innovation process (Lhuillery and Pfister, 2009). The main motive for collaborating with competitors is risk and cost sharing in innovation projects by pooling similar resources (Miotti and Sachwald, 2003). However, firms within the same industry have the incentive to protect their knowledge as this is the main source of their competitive advantage. Therefore, competitors will systematically restrict the knowledge flow and engage in opportunistic behaviour that could lead to a failure of joint R\&D project (Lhuillery and Pfister, 2009). This may be especially pronounced for SMEs operating in low and medium tech industries as they seldom use formal means to protect their intellectual property rights (Radicic and Pugh, 2017).

Cooperation with universities and research institutes may spur the creation of radical innovations as they provide cutting edge knowledge to a firm (Belderbos et al., 2004). In addition, engaging in university collaboration may be an attractive option for firms with limited investment in $\mathrm{R} \& \mathrm{D}$ as it allows inexpensive and low-risk access to a large and diverse knowledge base (Foreman-Pack, 2013; Radicic et al., 2019). Compared to vertical and horizontal types of cooperation, it entails the greatest ease of access, low risk of knowledge leakage and of opportunistic behaviour.

Given the prominent role of trust, firms are more likely to cooperate with government institutions which are willing to share knowledge while posing no commercial threat (Radicic et al., 2019). Since the likelihood of mistrust and appropriability issues is less likely to occur when cooperating with government institutions, SMEs in low and medium-tech sectors that usually do not engage in formal protection of intellectual property are more likely to engage in public-private partnerships.

Finally, cooperating with consultants, firms have access to deeper levels of expertise. Tether and Tajar (2008) found that similar factors determine relationships between firms and either specialist knowledge providers and public research organizations. They argue that firms with limited investment in $R \& D$ are more prone to cooperation with consultants as their intellectual property is mostly tacit in nature.

Although scarce, most empirical studies on behavioural additionality report positive policy effects. Of these, most report larger additionality effects for public-private partnerships than for cooperation with other businesses (Busom and Fernández-Ribas 2008; Radicic et al., 2018). 


\section{R\&D and innovation policy in the Western Balkans: Comparative perspective}

Despite some differences, the Western Balkan countries share common historic, institutional and market similarities. ${ }^{1}$ The region has experienced economic and political transition including the transition from war to peace in the 1990s. Economic transformation was mainly based on macroeconomic stabilization, trade liberalisation, enterprise privatization of traditional industries and attraction of FDI. However, recent financial crisis revealed weaknesses of an economic growth model based on expansion of domestic consumption, stagnant productivity and very limited integration into EU Global Value Chains (Radosevic, 2013). The emphasis on economic and political reforms had several consequences for research and the innovation sector. Strong reliance on capital inflows, deindustrialisation and excessive tertiarization accompanied by political instability and weak institutional frameworks led to declining importance of the research sector, low R\&D investment, brain drain, limited ICT utilisation, obsolete scientific equipment, weak abilities for university-industry collaboration and commercialisation of research results (Svarc, 2013). In addition, underdeveloped private sectors and dysfunctional market institutions coupled with relatively weak administrative capacities and a lack of cooperation and coordination among government agencies are obstacles to sustainable and coherent innovation policies (Matusiak and Kleibrink, 2018).

The WBs' innovation systems are characterised by highly centralised governance systems concentrated in the public sector, typical of less developed countries and technological followers that suffer from the lack of market forces and insufficient cooperation with innovation stakeholders inhibiting technological development (Svarc, 2013).

One of the major factors limiting the further development of research, development and innovation (RDI) is very low expenditure on research and development (Figure 1). GERD remains below $0.5 \%$ of GDP in most countries, except Serbia and Croatia where it reaches $0.9 \%$ and Slovenia which is an innovation-driven economy (Schwab et al., 2017).

\footnotetext{
${ }^{1}$ Although Slovenia does not formally belong to the Western Balkans, the country is included in the analysis due to strong historical and economic ties with the region.
} 
Figure 1. Gross domestic expenditure on R\&D (GERD) as \% of GDP, 2015

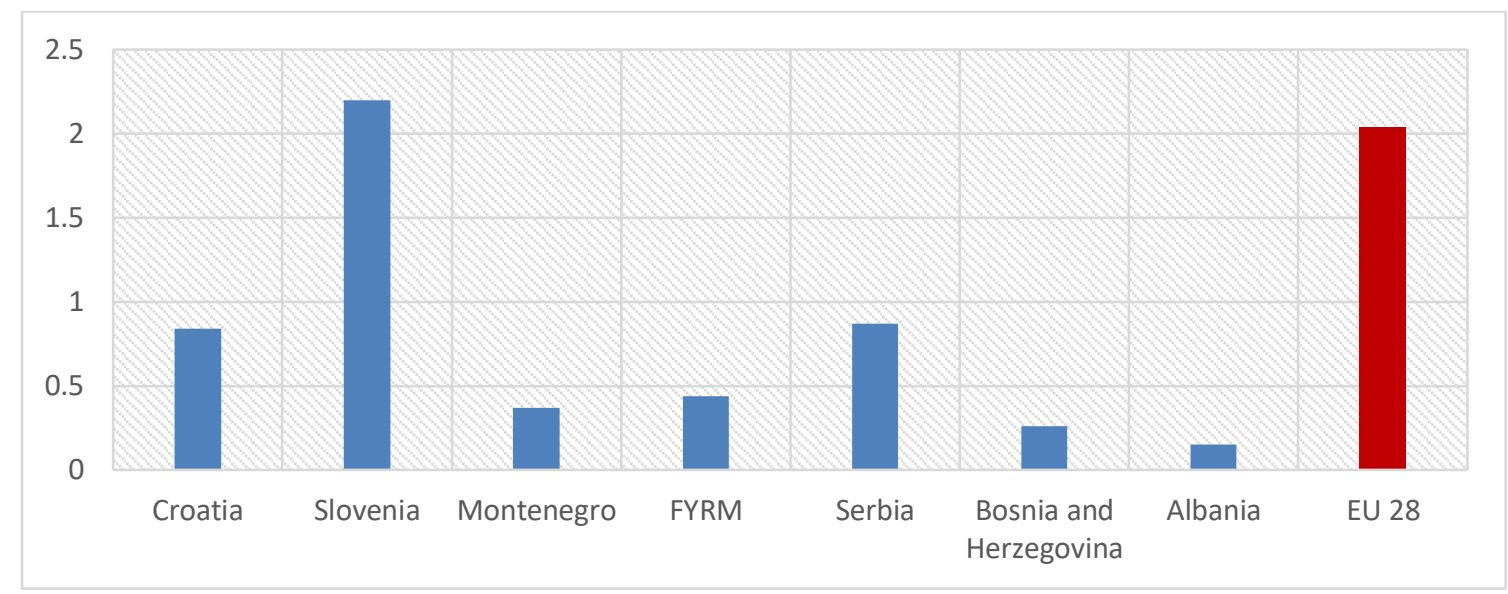

Source: Eurostat Gross Domestic Expenditure on R\&D (GERD) and Unesco Science Report (2016)

Note: 2014 for Bosnia and Herzegovina; 2008 for Albania

This is still well below the EU average and far below the investments needed to create resources for technological accumulation and knowledge based-economy (Svarc, 2013).

Business R\&D expenditure as percentage of GDP is only a fraction of that in the EU (Figure 2). As an illustration, in B\&H and FYRM it accounted for only $0.05 \%$ and $0.08 \%$, respectively, while in the EU it reached $1.31 \%$. Despite underinvestment in $R \& D$, recent data from European Innovation Scoreboard suggest that self-reported innovation in firms is higher in Bosnia and Herzegovina and Serbia in comparison to new member states. The levels of product and process innovation in Serbia and FYRM is comparable to the EU average of 13\% (OECD, 2018). Given their low levels of R\&D investment, we can infer that most of these innovations are nontechnological in nature which can also be supported by high levels of investment in non-R\&D innovation expenditure (EC, 2017). 
Figure 2. Business expenditure on R\&D, \% of GDP, 2015

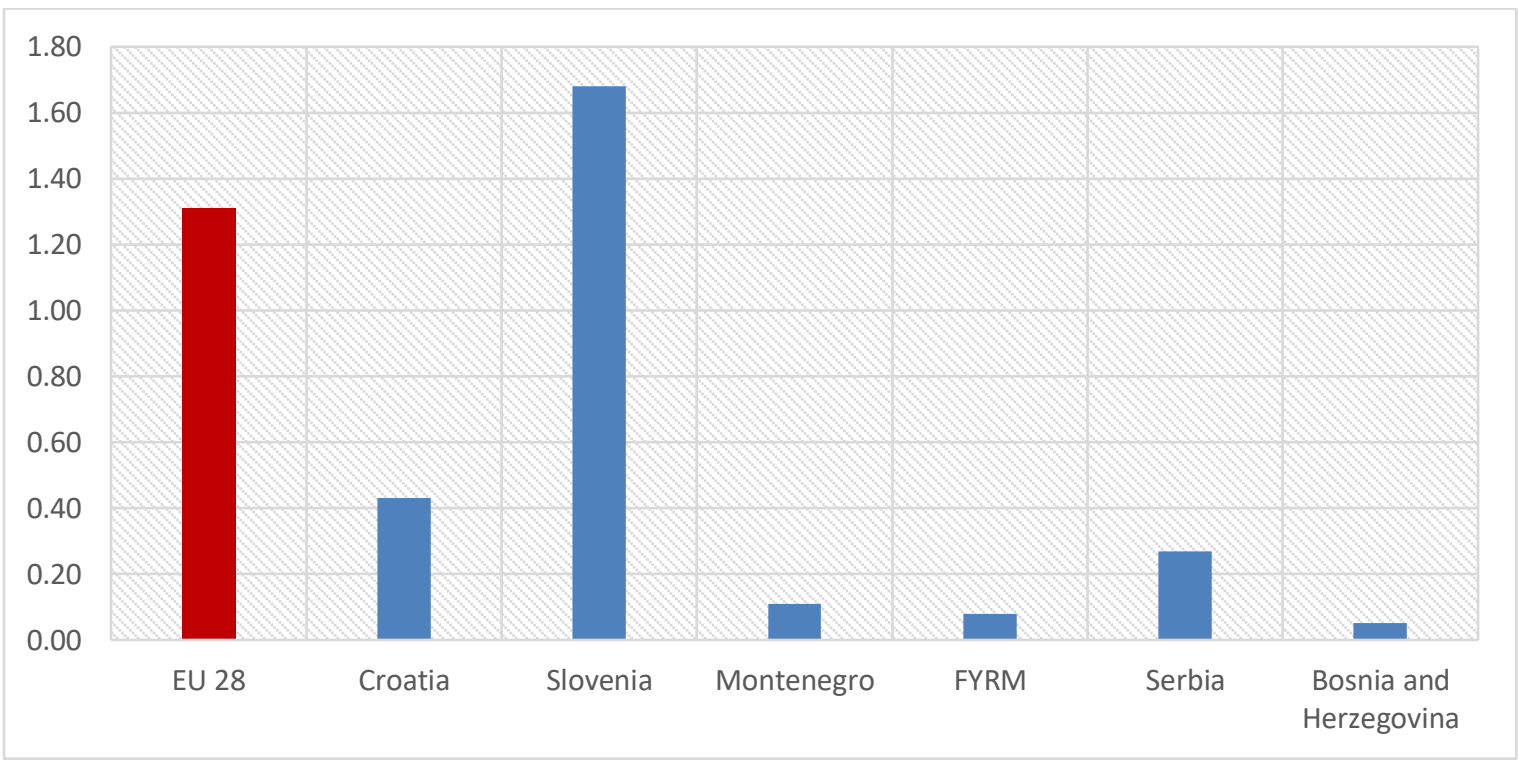

Source: Eurostat Business Expenditure on R\&D (BERD)

Note: 2014 for Bosnia and Herzegovina

The decreasing propensity to invest in R\&D can also be inferred from significant brain drain. The migration of large number of scientists, engineers and technicians during the first decade of transition significantly reduced the region's research capacity. On the positive side, enrolment to higher education has increased in the last decade which has also translated into a higher number of researchers in absolute and per capita terms, although still below levels in other EU countries (Unesco, 2016). However, most of them are employed in academia, reflecting low demand for business R\&D reported in Figure 2.

One of the most underdeveloped elements of institutional support is related to financial tools available for development and commercialization of inventions. Access to finance is still one of the major constraints in the region (EBRD, 2016) which has important implications for innovation-oriented entrepreneurship. Gorodnichenko and Schnitzer (2013) find that firms operating in countries with more severe financial constraints are less likely to engage in innovation, with the greatest detrimental effect found in countries with high costs of external finance and among small and young firms. The WBs is not an exception as low demand for credit from the private sector is partially attributable to the high costs of borrowing and lack of 
investment readiness (OECD, 2018). The supply of venture capital is absent or in very early stages, mostly available in Slovenia and Croatia. ${ }^{2}$

The WBs' technological effort at the world frontier, as measured by the US patents, is limited. The region applied for 38 patents in the United States in 2012, compared to an average of 25 patents for the leading US research universities and institutions (World Bank, 2013). Similarly, patents, granted by the United States Patent and Trademark Office (USPTO) per million inhabitants in the period 2002-2013 show a significant variation between countries. Croatia (45.9) and FYROM (25.6) are clearly the frontrunners in comparison to other countries where this number is extremely low. A low productivity of the regional innovation system is an additional evidence of a weak technological transfer. As an illustration, a unit of Croatian or Serbian US registered patents has required between four and eight times more R\&D expenditures, respectively, than a German patent (World Bank, 2013).

In sum, the discussion above points to an "innovation paradox" where the need for innovation and catch up in less developed economies is high but institutional context and factor endowments may be lacking (Oughton et al., 2002). Moreover, institutional features inherited from centrally planned system along with economic and institutional restructuring during the transition period have resulted in a variety of country-specific patterns of innovation activities as evident from the aforementioned discussion.

\section{Survey, data and methodology}

\subsection{Survey and data}

The dataset used in this study was gathered in 2014 within the Pacinno project funded by the IPA (Instrument for Pre-Accession Assistance) Cross-Border Cooperation Programme. ${ }^{3}$ The

\footnotetext{
${ }^{2}$ Recently, a set of complementary measures for improving access to finance for SMEs has been launched coordinated by the European Investment Fund, the European Commission and the European Bank for Reconstruction and Development. The Enterprise Development and Innovation Facility aims to improve access to finance by SMEs in the region. It consists of three components: Enterprise Innovation Fund (ENIF) aimed at early development stage equity financing in innovative SMEs; Enterprise Expansion Fund (ENEF) providing development and expansion capital to established high-growth potential SMEs; and Regional Guarantee Facility aimed at improving SMEs' access to bank lending and lowering the cost of borrowing, by providing SME loan portfolio guarantees to financial intermediaries.

3 For more information about the project, see https://hilab.di.ionio.gr/pacinno/. The Pacinno project is a collaboration platform that connects into a single regional innovation system researchers and academic institutions, policy makers, and innovative companies of eight countries belonging to the Adriatic region (Albania, Bosnia-Herzegovina, Croatia, Greece, Italy, Montenegro, Serbia, and Slovenia). The goal of the project was to establish a platform for cooperation in research and innovation covering the whole Adriatic region. The project targeted research institutions, policy makers and firms, through three key areas of action: research of innovation on micro, meso and macro level, training of human resources and knowledge and technology transfer. More generally, the project was aimed at overcoming the main obstacles and barriers to the economic development of
} 
survey was conducted between May 2014 and December 2014 and most questions refer to the period 2011-2013. The questionnaire was developed partially using the Community Innovation Survey (CIS) methodology, a widely used source of information about innovation activities of firms across EU. However, CIS only partially covers Serbia and does not cover B\&H, Montenegro and Albania, thus our data represent one of the few sources on innovation activities in these countries.

Project members anticipated the practical difficulty with obtaining a large number of responses from SMEs. One corollary of the anticipated low response rate was that simple representative sample of SMEs would include an insufficient number of firms engaged in innovative activities. Therefore, a stratified random sampling method was used in all countries ${ }^{4}$ based on the overall population of micro, small and medium firms, but biased towards more innovative sectors. The innovative sector was determined from official secondary data, when available; otherwise researchers from the specific country made the decision. To this end, a two-fold approach was implemented by partners on the project. First, to align the sample frame as closely as possible to the target population, a list of SMEs was taken from official sources such as Chambers of Commerce or National statistical offices and they were approached via email addressed to the company legal representative. Secondly, to ensure an adequate number of firms in each country and to address initial low response rates in Serbia and Albania, the companies were contacted by telephone to organize a meeting. After that, a team visited companies in person and filled the survey on the site.

After partially completed surveys have been omitted (with cut-off criteria of at least $10 \%$ of missing values), the sample amounted to 646 SMEs. Response rate range from $27 \%$ in Montenegro to only 5.4\% in Slovenia (Table 1), which is similar to other surveys (Souchon et al., 2015). Due to a significant number of missing values, the effective sample in our analysis vary from 141 to 204 observations.

\section{Table 1. Response rates by country}

the Adriatic countries, fostering SME competitiveness (both in the high-tech fields and in the traditional industries), and promoting the creation of innovative start-ups, increasing the innovation capacity of the Adriatic Region and enabling the transfer of best practices across particular countries of the Region.

\footnotetext{
${ }^{4}$ Croatia, Albania, Bosnia and Herzegovina, Montenegro, Slovenia and Serbia.
} 


\begin{tabular}{lcccccc}
\hline & Slovenia & Croatia & Albania & B\&H & Montenegro & Serbia \\
\hline Response rate (\%) & 5.4 & 18 & 24 & 19 & 27 & 15 \\
\hline Completed surveys & 92 & 149 & 107 & 109 & 118 & 71 \\
\hline
\end{tabular}

While detailed breakdowns are relegated to the Appendix (Table A.1), we summarize the main findings of comparative analysis between subsidized and non-subsidized firms. As far as subsidized firms are concerned, the majority is concentrated in the knowledge intensive services and high-tech manufacturing sectors (53.5\%). Subsidized firms are also more likely to engage in export (72\%) and cooperate with external partners $(62 \%)$ versus non-subsidized firms (60\% and $43 \%$, respectively). Despite the fact that non-subsidized firms have a higher propensity to invest in $R \& D$ then subsidized firms, analysis of innovation outcomes between the two groups of firms show that subsidized firms are more likely to engage in product, radical and incremental innovation, although for the latter there is no statistically significant difference between the two groups. When it comes to cooperation, there is a statistically significant difference between subsidized and non-subsidized firms across all modes of cooperation except with suppliers. Looking at the cooperation figures, subsidized firms develop more cooperative ties.

\subsection{Variables}

The treatment variable (Support) is a binary indicator equal to 1 if a firm received any public financial support for innovation activities either from local/regional, national or EU level in the period 2011-2013, and zero otherwise (Radicic et al, 2016). In investigating input additionality, we use the outcome variable $R \& D$, which is a binary indicator equal to 1 if a firm invested in internal or external R\&D and zero otherwise. As for the output additionality, we use four binary variables that capture whether firms introduced product, process, incremental and radical innovations and the share of turnover of new or significantly improved products as a measure of the market success of product innovation (i.e. innovative sales). Finally, for behavioural additionality, the seven outcome variables measuring firms' cooperation activities are used to identify firms involved in different forms of R\&D cooperation. They are defined as binary indicators equal to 1 if the firm cooperates with the following potential partners (and zero otherwise): suppliers; customers; competitors; consultants; HEIs; and government institutions. We also created the variable Coop_breadth by measuring the number of cooperative partners 
or cooperation breadth, which captures the networking effect of R\&D arrangements (Beker and Dietz, 2004). Besides network additionality, to capture changes in firms' behaviour that augment their absorptive capacity, we created the variable Training, which is a binary variable equal to 1 if the firm has in-house or contracted out training for personnel specifically for the introduction of new or significantly improved products and processes, and zero otherwise. Public support could have an impact on the creation of absorptive capacity which may induce high levels of new technology adoption and the introduction of technological innovation. ${ }^{5}$

Control variables account for the heterogeneity of firms with respect to their size, exporting activities and financial performance. Previous empirical literature found close correlation between firm size and innovation output (Beneito, 2006; Veugelers and Cassiman, 1999). We controlled for firm size by using the natural log of employment. Exporters might have more incentive to innovate as a result of competitive pressure on international markets and thus be more likely to self-select into public support programmes (Busom and FernándezRibas, 2008). In addition, exporters potentially have a larger network of cooperation partners than do non-exporting firms.

We also control for different governance structure. Our assumption is that network connections arising from belonging to a group enables firm to have better access to information about government actions and, consequently, increase chances of receiving subsidies (Aerts and Schmidt, 2008). Furthermore, the model includes four variables capturing different sources of external knowledge: internal, market, institutional and other sources. Finally, the model includes a dummy variable for non-EU countries: Albania, Bosnia and Herzegovina, Macedonia, and Serbia (see Table A1 for variable description and descriptive statistics). Similar to other studies (e.g. Ballot et al., 2015), we control for industry heterogeneity by grouping sectors based on their technology intensity using OECD classification.

\subsection{Methodology}

A critical element of any evaluation exercise is a proper modelling of participation in support programmes. Namely, treatment assignment into support measures should be regarded as endogenous due to selection bias arising in the process of application and distribution of public measures. The selection bias occurs because a) firms self-select themselves into programmes, and b) the government adopts a 'picking-the-winner' strategy during the selection process (selecting those firms that are more likely to succeed with their project) (Cerulli, 2010).

\footnotetext{
${ }^{5}$ We thank an anonymous referee for this point.
} 
Concerning behavioural additionality, endogeneity of public support would imply that the probability of establishing and maintaining cooperative relationships is correlated with the receipt of innovation support, in which case estimated programme effects would be biased and inconsistent. Namely, some support programmes do explicitly address cooperation as an output and so might be subject to biased selection by programme managers; and, those firms most inclined to cooperate may be the ones with the greatest propensity to self-select into support programmes (Czarnitzki and Delanote, 2015; Foreman-Pack, 2013).

In order to reduce sample selection bias we adopt propensity score matching (PSM) technique. Since it is not possible to observe the same firm in two different scenarios (with and without R\&D support) we create a counterfactual using a firm with very similar characteristics in all respects other than receiving $R \& D$ support. The central feature of matching analysis is the relationship between a treatment variable (R\&D support) and the outcome variables defined in the previous section.

We estimate the Average Treatment Effect on the Treated (ATT), which indicates the difference in outcomes of the treated firms with and without treatment and can be written as:

$$
A T T=E\left[Y_{1} \mid T=1\right]-E\left[Y_{0} \mid T=1\right]
$$

The first term on the right-hand side of Eq. (1), $E\left[Y_{1} \mid T=1\right]$, is the expected outcome for subsidised firms conditional on their participation, while the second term $E\left[Y_{0} \mid T=1\right]$ is the expected outcome had treated firms not participated in the public support programme. This second term refers to a counterfactual outcome that is not observed but estimated. To estimate the ATT effect, it is necessary to assume that all relevant differences are captured in the observed attributes of the treated and untreated firms. That is, no bias from selection on unobservables is present, otherwise matching yields biased estimates (Caliendo and Kopeinig 2008). To define propensity score we used a logit model to identify and summarize the key characteristics of treated firms. Once we have obtained propensity scores, we match treated with comparable untreated firms.

Having a large number of relevant variables is of high importance particularly when matching estimators are applied, given that the assumption of selection on observables critically hinges on the inclusion of all variables affecting the innovation process. However, because the selection on observables is achieved by matching the treatment and the comparison group, obtaining the appropriate size of the common support (i.e. matched pairs) requires a large dataset (Cerulli, 2010). Following Caliendo and Kopeinig (2008), asymptotically all 
matching estimators should yield similar results. However, finite properties of various matching algorithms are not fully explored. Hence, in small samples like ours, the choice of the matching algorithm can be important (Heckman et al., 1997), which usually includes a trade-off between variance and bias. For this reason, the literature on matching estimators suggests that researchers should use several matching estimators, as there is no consensus on which estimator is superior to others (Guo and Fraser, 2010).

As a robustness check, we apply the following two estimators. Nearest Neighbour (NN) matching is the most commonly used estimator in the innovation literature (Herrera and Nieto 2008). In applying the Nearest Neighbours (NN) estimator, subsidized (treated) firms are matched with non-subsidized firms (as a control group) with the closest estimated propensity scores. We also used Inverse Probability of Treatment Weighting (IPTW). The crucial step in the matching procedure is the choice of covariates $X$. The literature suggests that all observed variables that simultaneously affect a treatment and an outcome should be included in the estimation of propensity scores (the selection equation) (Caliendo and Kopeinig, 2008). Following Steiner et al. (2010), in situations when researchers have little or no information on the selection mechanism (which is usually the case in innovation studies), the optimal modelling strategy is to include a large set of covariates, because this approach increases the probability of satisfying the assumption of selection on observables.

The final step in the matching process is to assess its effectiveness. Matching as an evaluation method is based on two identifying assumptions. The first is the conditional independence assumption (CIA), unconfoundedness or selection on observables (Imbens 2004). This condition states that both counterfactual outcomes, $Y_{0}$ and $Y_{l}$, are independent of a treatment assignment $T$, conditional on observed covariates $X$. The CIA is a strong assumption and requires that all relevant observed variables are included in the estimation of treatment effects and that variables are measured before treatment assignment (or that they measure fixed effects or slow-moving firm characteristics). The second refers to the overlap or common support condition, which states that both treated and non-treated firms have a positive probability of receiving a treatment or not (thus avoiding perfect predictability of a treatment assignment conditional on $X$ ).

As noted above, matching estimators cannot control for unobserved characteristics, which creates two additional issues in evaluating public measures: treating the selection process as a 'black box'; and producing potentially biased treatment effects. Given that researchers do not possess information on the quality of the proposed $R \& D$ projects (Grilli and Murtinu, 2011), assuming that unobserved factors have no impact on the treatment effects will 
give rise to biases in the estimated treatment effects. In this context, we conducted an additional robustness check by estimating a copula-based endogenous switching model (see Section 5.1 below), which accounts for both observed and unobserved firm heterogeneity.

\section{Results of the empirical analysis}

The correlation matrix showing the Pearson correlation coefficients among the independent variables is presented in Table A2 in Appendix. The correlations are overall low to moderate suggesting that multicollinearity is minimal. To further assess potential problems with multicollinearity, the variance inflation factor (VIF) and the conditioning index were calculated. The former is 1.34 , which is substantially lower than the conservative cut-off of 10 (Fernández-Olmos and Ramírez-Alesón, 2017), while the latter is 18.24, which is below the cut-off value of 20 (Greene, 2012, p. 90). These results suggest that the regression estimates are not biased by the presence of multicollinearity.

The propensity scores estimated by logit models are shown in Table A3. The literature on matching suggests the inclusion of even those covariates that are statistically insignificant, because their inclusion does not increase bias in subsequent matching estimations (Millimet and Tchernis, 2009). Moreover, our study is limited by a lack of information on the selection process, which means that a large number of covariates should be modelled in the estimation of the propensity score. Furthermore, models that evaluate output and behavioural additionality include R\&D expenditures as an additional matching variable. Czarnitzki and Lopes-Bento (2013) note that the inclusion of the innovation input indicator, such as R\&D expenditures, enables the matching algorithm to find suitable matches between treated and untreated firms, but with the same level of investment in R\&D expenditures.

Treatment effects of any matching estimator based on the propensity score are only estimated in the region of common support. Thus, it is necessary to check the overlap of the propensity scores such that both treated and untreated firms have a positive probability of receiving a treatment or not. The overlap plots, reported in Figure A1, reveal that the predicted probabilities are not concentrated near 0 or 1 , which implies that the overlap assumption is not violated (Cattaneo et al., 2013). Having verified the balancing property, we can proceed with the computation of ATT effects.

Table 2 presents the Average Treatment on the Treated (ATT) effects estimated by Propensity Score Matching (PSM), Nearest Neighbour (NN) and Inverse Probability of 
Treatment Weighting (IPTW). The treatment effects are fairly consistent across the three matching estimators. Concerning input additionality, the results uniformly indicate no additional effects of public support on R\&D activities. With respect to output additionality, empirical findings are mostly consistent and suggest no additional effects of public support on innovation outputs. There is weak evidence that public support might increase the share of sales from new products (i.e. innovative sales) (the estimated ATT from NN matching is positive and marginally significant; $\mathrm{p}<0.10$ ), but this result is not robust with respect to different matching estimators.

Table 2. Estimated Average Treatment Effects on the Treated (ATT) using three estimators: Propensity Score Matching (PSM), Nearest Neighbour (NN) and Inverse Probability of Treatment Weighting (IPTW).

\begin{tabular}{|c|c|c|c|c|}
\hline \multirow[t]{2}{*}{$\begin{array}{l}\text { Outcome } \\
\text { variables }\end{array}$} & PSM & NN matching & $\begin{array}{l}\text { IPTW } \\
\text { estimator }\end{array}$ & \multirow[t]{2}{*}{$\begin{array}{c}\text { Number of } \\
\text { obs. }\end{array}$} \\
\hline & $\begin{array}{c}\text { ATT } \\
\text { (Abadie and }^{\text {Imbens SEs) }}{ }^{\mathrm{a}}\end{array}$ & $\begin{array}{c}\text { ATT } \\
\text { (Abadie and } \\
\text { Imbens SEs) }\end{array}$ & $\begin{array}{c}\text { ATT } \\
\text { (robust SEs) }\end{array}$ & \\
\hline \multicolumn{5}{|c|}{ Input additionality } \\
\hline $\begin{array}{l}\text { R\&D (internal or } \\
\text { external) }\end{array}$ & $\begin{array}{l}-0.063 \\
(0.113)\end{array}$ & $\begin{array}{l}-0.083 \\
(0.107)\end{array}$ & $\begin{array}{l}-0.107 \\
(0.089)\end{array}$ & 204 \\
\hline \multicolumn{5}{|c|}{ Output additionality } \\
\hline $\begin{array}{l}\text { Product } \\
\text { innovation }\end{array}$ & $\begin{array}{c}0.104 \\
(0.099)\end{array}$ & $\begin{array}{c}0.083 \\
(0.089)\end{array}$ & $\begin{array}{c}0.089 \\
(0.080)\end{array}$ & 203 \\
\hline $\begin{array}{l}\text { Process } \\
\text { innovation }\end{array}$ & $\begin{array}{c}0.021 \\
(0.061)\end{array}$ & $\begin{array}{c}0.000 \\
(0.064)\end{array}$ & $\begin{array}{l}-0.032 \\
(0.059)\end{array}$ & 204 \\
\hline $\begin{array}{l}\text { Radical } \\
\text { innovation }\end{array}$ & $\begin{array}{c}0.175 \\
(0.139)\end{array}$ & $\begin{array}{c}0.050 \\
(0.079)\end{array}$ & $\begin{array}{c}0.103 \\
(0.087)\end{array}$ & 166 \\
\hline $\begin{array}{l}\text { Incremental } \\
\text { innovation }\end{array}$ & $\begin{array}{c}-0.100 * * \\
(0.049)\end{array}$ & $\begin{array}{c}0.075 \\
(0.089)\end{array}$ & $\begin{array}{c}0.023 \\
(0.084)\end{array}$ & 166 \\
\hline Innovative sales & $\begin{array}{c}0.094 \\
(0.069)\end{array}$ & $\begin{array}{l}0.121^{*} \\
(0.071)\end{array}$ & $\begin{array}{c}0.040 \\
(0.064)\end{array}$ & 160 \\
\hline \multicolumn{5}{|c|}{ Behavioural additionality } \\
\hline $\begin{array}{l}\text { Cooperation } \\
\text { with suppliers }\end{array}$ & $\begin{array}{c}0.051 \\
(0.082)\end{array}$ & $\begin{array}{c}-0.154 * * \\
(0.061)\end{array}$ & $\begin{array}{l}-0.029 \\
(0.071)\end{array}$ & 157 \\
\hline $\begin{array}{l}\text { Cooperation } \\
\text { with customers }\end{array}$ & $\begin{array}{c}0.026 \\
(0.117)\end{array}$ & $\begin{array}{l}-0.079 \\
(0.081)\end{array}$ & $\begin{array}{l}-0.041 \\
(0.073)\end{array}$ & 157 \\
\hline $\begin{array}{l}\text { Cooperation } \\
\text { with competitors }\end{array}$ & $\begin{array}{c}0.412 * * * \\
(0.146)\end{array}$ & $\begin{array}{c}0.206 \\
(0.126)\end{array}$ & $\begin{array}{c}0.286 * * * \\
(0.094)\end{array}$ & 150 \\
\hline $\begin{array}{l}\text { Cooperation } \\
\text { with consultants }\end{array}$ & $\begin{array}{l}0.323 * * \\
(0.150)\end{array}$ & $\begin{array}{l}0.326 * * \\
(0.127)\end{array}$ & $\begin{array}{c}0.313 * * * \\
(0.104)\end{array}$ & 145 \\
\hline $\begin{array}{l}\text { Cooperation } \\
\text { with HEIs }\end{array}$ & $\begin{array}{c}0.139 \\
(0.111)\end{array}$ & $\begin{array}{l}0.278^{* *} \\
(0.126)\end{array}$ & $\begin{array}{l}0.191^{*} \\
(0.113)\end{array}$ & 150 \\
\hline $\begin{array}{l}\text { Cooperation } \\
\text { with government }\end{array}$ & $\begin{array}{c}0.611 * * * \\
(0.083)\end{array}$ & $\begin{array}{c}0.500 * * * \\
(0.095)\end{array}$ & $\begin{array}{c}0.442 * * * \\
(0.111)\end{array}$ & 149 \\
\hline
\end{tabular}




\begin{tabular}{lcccc}
\hline Cooperation & $1.323 * * *$ & $1.129 * * *$ & $1.357 * * *$ & 141 \\
breadth & $(0.400)$ & $(0.380)$ & $(0.322)$ & \\
\hline Training & 0.167 & 0.042 & $0.170 *$ & 147 \\
& $(0.109)$ & $(0.110)$ & $(0.095)$ & \\
\hline
\end{tabular}

Notes: ***, **, * ATT estimated at the one, five or ten per cent level of significance; ${ }^{a}$ Abadie and Imbens (2009) derived a method for variance estimation for NN matching which is applied in this study.

Finally, the only additional effect presented in the Table 2 is associated with behavioural additionality. Namely, the results suggest that public support positively affects cooperation with consultants and with government institutions. Furthermore, there is weak evidence that public support might induce firms to expand their cooperation with competitors and universities (and other HEIs), but these results are not robust across different matching estimators. Regarding vertical cooperation with customers and suppliers, our results uniformly indicate no additional effects. In contrast, for cooperation breadth the estimated treatment effects are consistent, positive and highly statistically significant. Namely, receiving public support induces firms to expand their cooperative networks by, on average, one partner $(\mathrm{p}<0.01) .{ }^{6}$ In relation to the impact of public support on training activities, our results suggest no significant effect.

\subsection{Further robustness check}

Given that the main disadvantage of matching estimators is that they only take into account endogeneity due to the selection on observables (as noted in Section 4.3), our further robustness check is conducted by estimating a sample-selection model. This model controls for both selection on observed and unobserved heterogeneity. However, empirical results from this model should be considered with caution, because our dataset does not contain a valid instrument, i.e. the exogenous variable that would be correlated with the endogenous variable (i.e. treatment variable) but would have no effect on the outcome variable. In other words, as the model relies only on the functional form, the identification problem can introduce bias in the standard errors (Cerulli, 2010).

In particular, we estimate a copula-based endogenous switching regression model (also known as a Roy model or a type 5 tobit model, Hasebe, 2013). The main advantage of the

\footnotetext{
${ }^{6}$ As pointed in footnote 1 , Slovenia does not formally belong to the Western Balkans. As a further robustness check, we estimated the models from Table 2 without Slovenian firms. The results are shown in Table A4 in Appendix. Qualitatively, they are the same as the main results, except for input additionality measured with R\&D, for which our estimates tentatively suggest additional effects, as the treatment effect is not robust across all three estimators.
} 
copula approach is that the assumption of a joint normality of the error terms in the outcome and selection equations is relaxed (Smith, 2003). Another advantage is that the copula method allows the model to be estimated via the maximum likelihood method, which means that the estimates are efficient (Hasebe, 2013). A copula represents a joint distribution function that binds together marginal distributions of the error terms in the selection and the outcome equations, although the copula itself is independent of marginal distributions (Smith, 2003). In our analysis, we have considered a range of copulas: Gaussian; Frank; Plackett; Clayton; AMH; FGM; Joe; and Gumbel (for detailed discussion see Hasebe, 2013; Smith, 2003). In each of the estimated models reported below, the preferred copula was determined using the Vuong test together with the AIC and BIC information criteria. The former evaluates the contribution of each copula to the log likelihood, such that the copula with the highest contribution is preferred. In addition, the smallest AIC or BIC suggests the preferred copula (Hasebe, 2013; Smith, 2003).

The results from the copula models are presented in Table 3 below. Column 3 reports the Likelihood Ratio test of the null that the errors from the equations of the estimated switching model are independent (these diagnostics support the validity of the switching model). For the estimates for input and output additionality, p-values for the LR tests are all below the conventional five per cent threshold, which suggest that we can reject the null of the independent error terms in the equations of the corresponding switching models. Therefore, there is no diagnostic failure at the conventional five percent level in these models. For the estimates for behavioural additionality, there are three models for which the independence assumption does not hold at the conventional five percent level: cooperation with consultants; cooperation with HEIs; and training. Although the independence assumption cannot be rejected at the five per cent level, it can be rejected at the ten per cent level. Therefore, there is a marginal evidence of the dependence in error terms. As the theory suggests that receiving public support for innovation is endogenous, and thus an endogenous switching model should be estimated, we are inclined to accept a marginal evidence of the dependence in error terms. Moreover, when the independence assumption cannot be rejected, two independent equations can be estimated as their estimates will be consistent (Miranda and Rabe-Hesketh, 2006).

Although most results are consistent with findings from matching estimators, we comment on those that are different from matching. First, the treatment effect related to input additionality, in particular R\&D activities, is positive and highly statistically significant (at the $1 \%$ level). We interpret these results as a potential additional effect that public support might have on innovation inputs, although, again, these results are tentative. Second, concerning 
output additionality, the results from the copula models suggest that public support increases the probability of incremental innovation and the share of sales from innovative products. Third, with respect to behavioural additionality, the results from the copula models are consistent with the results from matching, in cases where additional effects are reported. However, unlike the results from matching, the results from the copula models indicate the crowing-out effects of public support on cooperation with suppliers, customers, competitors and HEIs. These findings are in line with Greene's (2009) conjecture that evaluation methods controlling for unobservable influences find smaller programme effects than do methods controlling only for observable influences (Radicic et al., 2016).

Table 3. Average treatment effects on the treated (ATTs) using the copula approach (bootstrapped standard errors, 1,000 replications)

\begin{tabular}{|c|c|c|c|}
\hline Outcome variable & Copula & $\begin{array}{c}\text { LR test of } \\
\text { independence }\end{array}$ & $\begin{array}{l}\text { ATT } \\
\text { (SEs) }\end{array}$ \\
\hline R\&D expenditures & Joe & $\mathrm{p}=0.0047$ & $\begin{array}{c}0.837 * * * \\
(0.023)\end{array}$ \\
\hline Product innovation & Plackett & $\mathrm{p}=0.0287$ & $\begin{array}{c}-0.363 * * * \\
(0.001) \\
\end{array}$ \\
\hline Process innovation & Plackett & $p=0.0000$ & $\begin{array}{c}-0.399 * * * \\
(0.001)\end{array}$ \\
\hline Radical innovation & Plackett & $p=0.0004$ & $\begin{array}{c}-0.439 * * * \\
(0.004)\end{array}$ \\
\hline Incremental innovation & Plackett & $\mathrm{p}=0.0082$ & $\begin{array}{c}0.547 * * * \\
(0.005)\end{array}$ \\
\hline Innovative sales & Plackett & $\mathrm{p}=0.0023$ & $\begin{array}{c}0.751 * * * \\
(0.017)\end{array}$ \\
\hline $\begin{array}{l}\text { Cooperation with } \\
\text { suppliers }\end{array}$ & Frank & $\mathrm{p}=0.0323$ & $\begin{array}{c}-0.226 * * * \\
(0.000) \\
\end{array}$ \\
\hline $\begin{array}{l}\text { Cooperation with } \\
\text { customers }\end{array}$ & Plackett & $p=0.0176$ & $\begin{array}{c}-0.404 * * * \\
(0.002)\end{array}$ \\
\hline $\begin{array}{l}\text { Cooperation with } \\
\text { competitors }\end{array}$ & $\mathrm{AMH}$ & $\mathrm{p}=0.0058$ & $\begin{array}{c}-0.861 * * * \\
(0.016) \\
\end{array}$ \\
\hline $\begin{array}{l}\text { Cooperation with } \\
\text { consultants }\end{array}$ & $\mathrm{AMH}$ & $p=0.0946$ & $\begin{array}{c}0.314 * * * \\
(0.009)\end{array}$ \\
\hline Cooperation with HEIs & Clayton & $p=0.0670$ & $\begin{array}{c}-0.265 * * * \\
(0.000)\end{array}$ \\
\hline $\begin{array}{l}\text { Cooperation with } \\
\text { government }\end{array}$ & Frank & $\mathrm{p}=0.0434$ & $\begin{array}{c}0.140^{* * * *} \\
(0.003)\end{array}$ \\
\hline Cooperation breadth & Plackett & $\mathrm{p}=0.0000$ & $\begin{array}{c}0.256 * * * \\
(0.000) \\
\end{array}$ \\
\hline Training & Plackett & $\mathrm{p}=0.0852$ & $\begin{array}{c}-0.382 * * * \\
(0.003)\end{array}$ \\
\hline
\end{tabular}

Notes: *** ATT estimated at the one per cent level of significance. 


\section{Discussions and conclusion}

A key objective of this article was to evaluate whether R\&D subsidies induce additional treatment effects with respect to innovation inputs, outputs and $R \& D$ cooperation in SMEs in the WB countries. Despite a large number of evaluation studies on the impact of R\&D subsidies in the developed countries, there is a dearth of evidence in transition economics, and in particular in the WBs. Besides the lack of quantitative evaluation studies in the WBs, another less investigated issue is the effectiveness of $R \& D$ subsidies in promoting innovation in SMEs. Here, evidence is scarce, even in the case of firms in developed countries.

Our empirical evidence from three matching estimators uniformly show no additional treatment effects with respect to SMEs' innovation inputs and outputs. These results are somewhat expected if one knows that firms in the WBs are most likely to be innovation adapters and competitiveness tends to be driven by investment in higher education and training, the creation of efficient markets and the ability to absorb foreign technology, typical of efficiency driven economies. Therefore, the development of absorptive capacity at this stage is more important for catching-up than investment in $R \& D$ and it is likely that firms rely more on soft drivers for their innovation activities.

Another possibility is that while public support does not induce SMEs to increase innovation inputs and outputs, they instead allow firms to continue their R\&D and innovation activities at a constant level rather than cutting back. In other words, while public support may not have funded additional R\&D projects and innovation activities, they may have allowed firms to avoid eliminating ongoing innovation activities.

According to Autio et al. (2008), a dearth of empirical studies on behavioural additionality prevents the design of effective, evidence-based public policy. Our study contributes to addressing this lacuna by exploring the effectiveness of innovation support programmes on firms' cooperative behaviour. Concerning behavioural additionality, we find that public support does not promote cooperation with customers and suppliers, marginally promotes cooperation with competitors and universities, and strongly promotes cooperation with private-sector consultants and government institutions. These findings are in line with most previous empirical studies on behavioural additionality (Busom and Fernández-Ribas 2008; Radicic et al., 2018).

Furthermore, empirical findings from matching estimators indicate that full crowding out occurs in the case of innovation inputs and outputs. However, full crowding out may not 
constitute a complete waste of public funds, because the level of R\&D inputs and outputs are maintained and - by implication - resources thereby released that may support innovation over a period longer than can be captured by cross-sectional research. Such an interpretation receives support from the strong positive behavioural effects. These results echo the findings by Radicic et al. (2018), who report large behavioural effects of public support on cooperation in traditional manufacturing SMEs.

Positive policy effects on cooperation reported in the study could reflect the fact that the region is a target of many EU policies aimed at developing international cooperation and region's inclusion into EU Innovation programmes (Matusiak and Kleibrink, 2018). In particular, strong emphasis is put on measures supporting international collaboration in $R \& D$ and innovation. The latter accounts for almost $10 \%$ of gross domestic expenditure on R\&D (GERD) (OECD, 2018). Also, in recent years, the governments in the region are becoming more aware of challenges stemming from brain drain and low levels of international collaboration and research mobility. To tackle the issue, knowledge networks, provision of installation grants and funds for joint research between the local scientific community and scientific diaspora have been put in place (Svarc, 2013).

\subsection{Implications for theory}

The results of this study make two important contributions to existing literature. First, our findings suggest that evaluation studies of innovation support programmes should be designed to capture not only input and/or output additionality but also behavioural and systemic effects. While Georghiou (2002) argues that input and/or output additionality and behavioural additionality are substitutable, Clarysse et al. (2009) suggest that they are complementary. Our results provide preliminary support for Georghiou's (2002) argument. However, following Radicic et al. (2018), to investigate the dynamics of these two hypothesised processes will require the study of rich longitudinal data.

Second, this study adds new evidence on the effectiveness of public R\&D programs in transition economies. Scholars have little knowledge regarding whether R\&D support programmes might induce additional policy effects on SMEs' innovation activities in transition countries characterized by weak R\&D investments such as those of the WBs. Our results suggest the importance of improving appropriability mechanisms, expanding firms' limited absorptive capacity and the role of government in strengthening innovation ecosystems in the region which is further discussed in the next section. 


\subsection{Implications for policy}

Following Un and Montoro-Sanchez (2010), public funding increases the likelihood of innovation outputs but only when combined with firms' own resources. This could be particularly pertinent to SMEs in the Western Balkans, whereby these firms are faced with multiple issues with respect to innovation activities: insufficient internal human and financial resources; lack of or insufficient external finance (public as well as private, e.g. VCs and angel investors); and lack of other policy instruments, such as R\&D tax credits. Therefore, SMEspecific innovation policy in the Western Balkans should be designed to complement an overall innovation environment, in particular by strengthening the appropriation regime (Schneider and Veugelers, 2010) and providing private finance sources for risky investments in innovation. To tackle the problem of insufficient finances for innovation, a prominent new financing instrument has been recently introduced. The Enterprise Innovation Fund of the Western Balkans Enterprise Development and Innovation Facility finances innovative and technology-driven SMEs from the seed to expansion phase (OECD, 2018). Moreover, although not investigated in this study, public procurement for innovation, as a demand-side policy measure, has a potential to exert greater additional effects than supply-side measures. This could be particularly promising for the WB countries, as Tracogna (2016: 8) concludes concerning innovation policy in the Adriatic Region: “... governments' capabilities to effectively conceive and steer innovation ecosystems are limited."

Our finding show that public support induces firms in the Balkans to expand their cooperative network. This is in line with Tracogna (2016), who argue that concerning Adriatic Region, cooperation schemes between national and regional governments, business sectors and universities, technological institutes, technological parks/business incubators and research institutes need to be supported, while systemic cooperation between research and private/public companies should be reinforced.

Furthermore, public support that results in improved cooperation for innovation may enhance the functioning of innovation ecosystems and thus indirectly promote firms' innovative performance via the process of cumulative causation (i.e. policy effects go beyond short-run innovation input and output effects) (Radicic et al., 2018). Our results show the largest effect of R\&D subsidies on cooperation with government agencies and consultants and a potential for positive policy effects on cooperation with HEIs and competitors. Cooperation with universities and research institutes enables firms to tap into new knowledge from fundamental research (Ebersberger and Herstad, 2011; Un et al., 2010). Also, cooperation with 
public institutions and HEIs is characterized with mutual trust and lack of opportunistic behaviour, which, following discussion in Section 2.3., may yield favourable policy effects. Our empirical findings of a relatively weak positive effect of public support on cooperation with HEIs would seem to be a suitable topic for investigation by all parties concerned. There is another, unintended, but important by-product of strengthening firms' cooperative ties with HEIs. Namely, it would improve a research base of HEIs and their absorptive capacity, which would further strengthen innovation ecosystem in the WB countries.

Finally, public support can encourage cooperation between firms, HEIs and government, in which case strengthening the regions' HEIs and governmental institutions could feed back into enhanced absorptive and innovation capacity in firms. In turn, this poses multiple challenges to ensure that the whole incentive structure is aligned to facilitate cooperation and that innovation outcomes are monitored to prevent rent seeking by firms, HEIs and/or government personnel. ${ }^{7}$

\subsection{Limitations and directions for future research}

This study has limitations that remain to be addressed. The first is reverse causality. Within the limitations of our cross-section dataset, we are unable to control for unobserved heterogeneity, in particular with respect to previous innovation activities and cooperative behaviour. For instance, continually cooperating firms could be more likely to apply for funding, in which case public funding may be wrongly identified as a cause of cooperation behaviour. The second limitation concerns the extent of external validity. In the absence of sufficient observations to estimate policy effects separately by industry and country, we cannot conclude definitively that we have fully accounted for industry and country biases. While our results may reasonably be used to inform policy on public support for SMEs in the Western Balkans, policy makers should always be alert to the possibility of country and industry variations. The third limitation is that available data does not allow assessment of the effectiveness of public support on other types of behavioural additionality, such as cognitive capacity additionality. Fourth, since longitudinal data is not available, the way to gain direct evidence bearing on behavioural change may be by interviewing. Finally, cross-sectional data precludes exploration of the medium- to long-run programme effects.

\footnotetext{
${ }^{7}$ We thank an anonymous referee for this point.
} 


\section{References}

Aerts, K., Schmidt, T., 2008. Two for the price of one? Additionality effects of R\&D subsidies: A comparison between Flanders and Germany. Res. Policy 37 (5), 806-822.

Alecke, B., Mitze, T., Reinkowski, J., Untiedt, G., 2012. Does firm size make a difference? Analysing the effectiveness of R\&D subsidies in East Germany. German Econ. Rev. 13 (2) 174-195.

Antonioli, D., Marzucchi, A., Montresor, S, 2014. Regional innovation policy and innovative behaviour: looking for additional effects. European Plan. Stud. 22 (1), 64-83.

Antonioli, D., Marzucchi, A., 2012. Evaluating the additionality of innovation policy. A review focused on the behavioural dimension. World Rev. Sci., Techn. Sust. Devel. 9 (2/3/4), 124-148.

Arranz, N., de Arroyabe, J.C.F., 2008. The choice of partners in R\&D cooperation: an empirical analysis of Spanish firms. Technovation 28 (1-2), 88-100.

Arrow, K., 1962. Economic welfare and the allocation of resources for invention. In: Nelson, R. (Eds.), The rate and direction of inventive activity: Economic and social factors (pp. 609-626). Princeton University Press.

Autio, E., Kanninen, S., Gustafsson, R., 2008. First-and second-order additionality and learning outcomes in collaborative R\&D programs. Res. Policy 37(1), 59-76.

Bach L., Matt M., 2005. From Economic Foundations to S\&T Policy Tools: a Comparative Analysis of the Dominant Paradigms. In: Llerena P. and Matt M. (Eds.). Innovation policy in a knowledge based economy: theory and practice, Springer, Berlin.

Ballot G., Fakhfakh F., Galia F., Salter A., 2015. The fateful triangle: Complementarities in performance between product, process and organizational innovation in France and the UK. Res. Policy 44, 217-232.

Beck, M., Lopes-Bento, C., Wicki-Schenker, A., 2015. The Effectiveness of Public RD Subsidies and the Role of Collaboration. In: European Academy of Management Conference, Warsaw, 17 June 2015 - 20 June 2015.

Becker, W., Dietz, J., 2004. R\&D cooperation and innovation activities of firms-evidence for the German manufacturing industry. Res. Policy 33, 209-223.

Belderbos, R., Carree, M., Lokshin, B., 2004. Cooperative R\&D and firm performance. Res. Policy 33(10), 1477-1492.

Beneito, P., 2006. The innovative performance of in-house and contracted R\&D in terms of patents and utility models. Res. Policy 35(4), 502-517. 
Boschma, R., 2005. Proximity and innovation: A critical assessment. Reg. studies 39, 6174.

Bronzini, R., Piselli, P., 2016. The impact of R\&D subsidies on firm innovation. Res. Policy 45 (2), 442-457.

Busom, I., Fernández-Ribas, A., 2008. The impact of firm participation in R\&D programmes on R\&D partnerships. Res. Policy 37 (2), 240-257.

Caliendo, M., Kopeinig, S., 2008. Some Practical Guidance for the Implementation of Propensity Score Matching. J. Econ. Surveys 22 (1), 31-72.

Cassiman, B., Veugelers, R., 2002. R\&D cooperation and spillovers: some empirical evidence from Belgium. American Econ. Rev. 92(4), 1169-1184.

Cattaneo, M.D., Drukker, D.M., Holland, A.D., 2013. Estimation of multivalued treatment effects under conditional independence. Stata J. 13 (3), 407-450.

Cerulli, G., 2010. Modelling and Measuring the Effect of Public Subsidies on Business R\&D: A Critical Review of the Econometric Literature. Econ. Rec. 86 (274), 421-449.

Cerulli, G., Gabriele, R., Potì, B. 2016. The role of firm R\&D effort and collaboration as mediating drivers of innovation policy effectiveness. Ind. Innov. 23 (5), 426-447.

Chaminade, C., Lundvall, B.A., Haneef, S., 2018. National innovation systems. Edward Elgar, Cheltenham.

Chesbrough, H., 2003. Open Innovation: the new imperative for creating and profiting from technology. Harvard Business School Press, Harvard.

Chun H., Mun S-B., 2012. Determinants of R\&D cooperation in small and medium-sized enterprises. Small Bus. Econ. 39 (2), 419-436.

Clarysse, B., Wright, M., Mustar, P., 2009. Behavioural additionality of R\&D subsidies: A learning perspective. Res. Policy 38 (10), 1517-1533.

Cohen, W.M., Klepper, S., 1996. A reprise of size and R\&D. Econ. J. 106 (437), 925-951.

Crowley, F. and McCann, P., 2018. Firm innovation and productivity in Europe: evidence from innovation-driven and transition driven economies. Applied Economics 50 (11), 1203 1221.

Czarnitzki, D., Delanote, J., 2015. R\&D policies for young SMEs: input and output effects. Small Bus. Econ. 45 (3), 465-485.

Czarnitzki, D., Hottenrott, H., 2011. R\&D investment and financing constraints of small and medium-sized firms. Small Bus. Econ. 36 (1), 65-83.

Czarnitzki, D., Hussinger, K., 2018. Input and output additionality of R\&D subsidies. Applied Econ. 50 (12), 1324-1341. 
Czarnitzki, D., Lopes Bento, C., 2012. Evaluation of public R\&D policies: A cross-country comparison. World Rev. Sci. Technol. Sustain. Develop. 9(2-4), 254-282.

Czarnitzki, D., Lopes-Bento, C., 2013. Value for money? New microeconometric evidence on public R\&D grants in Flanders. Res. Policy 42(1), 76-89.

D’Este P., Guy F., Iammarino S., 2013. Shaping the formation of university-industry research collaborations: What type of proximity does really matter? J. Econ. Geog. 13, 537-558.

Dhont-Peltrault, E., Pfister, E., 2011. R\&D cooperation versus R\&D subcontracting: empirical evidence from French survey data. Econ. Innov. New Technol. 20 (4), 309-341.

De Jong, J.P., Vermeulen, P.A., 2006. Determinants of product innovation in small firms: A comparison across industries. Intern. Small Bus. J. 24 (6), 587-609.

Dimos, C., Pugh, G., 2016. The effectiveness of R\&D subsidies: A meta-regression analysis of the evaluation literature. Res. Policy 45 (4), 797-815.

EBRD, 2016. Transition report. London, UK.

Edquist, C., 2005. Systems of Innovation: Perspectives and Challenges. In: Fargerberg, J., Mowery, D.C., Nelson, R.R. (Eds.). The Oxford Handbook of Innovation. Oxford University Pres, New York, NY.

Elfring, T., Hulsink, W., 2003. Networks in entrepreneurship: The case of high-technology firms. Small Bus. Econ. 21, 409-442.

EC, 2017. European Innovation Scoreboard 2017, European Commission, Brussels, http://ec.europa.eu/growth/industry/innovation/facts-figures/scoreboards_fr.

Fernández-Olmos, M., Ramírez-Alesón, M., 2017. How internal and external factors influence the dynamics of SME technology collaboration networks over time. Technovation 64-65, 16-27.

Ferreira, J., Fernandes, C., Alves, H., Raposo, M., 2015. Drivers of innovation strategies: testing the Tidd and Bessant (2009) model. J. Bus. Res. 68 (7), 1395-1403.

Foreman-Peck, J., 2013. Effectiveness and efficiency of SME innovation policy. Small Bus. Econ. 41 (1), 55-70.

Georghiou, L., 2002. Impact and additionality of innovation policy. Innovation Science and Technology IWT Observatory, 40, pp.57-65.

Georghiou, L., Clarysse, B., 2006. Behavioural additionality of R\&D grants: introduction and synthesis. In: OECD (Eds.). Government R\&D funding and company behaviour: measuring behavioural additionality, pp. 9-38, OECD Publishing, Paris.

Gobble, M.M., 2014. Charting the innovation ecosystem. Res.-Technol. Manage. 57 (4), 5559. 
Gök, A., Edler, J., 2010. Exploring the use of behavioural additionality. In: Edler, J. (Eds.), INNOAppraisal: Understanding Evaluation of Innovation Policy in Europe. Report to European Commission DG Enterprise and Innovation, pp. 151-201, University of Manchester, Manchester Institute of Innovation Research, Manchester.

Gorodnichenko, Y., Schnitzer, M., 2013. Financial Constraints and Innovation: Why Poor Countries Don't Catch Up. J. European Econ. Assoc. 11 (5), 1115-1152.

Greene, F.J., 2009. Assessing the impact of policy interventions: the influence of evaluation methodology. Environ. Plann. C: Govern. Policy 27, 216-229.

Greene, W.H., 2012. Econometric analysis, 7th edition. NJ: Prentice Hall: Upper Saddle River.

Hagedoorn, J., 2002. Inter-firm R\&D partnerships: An overview of major trends and patterns since 1960. Res. Policy 31, 477-492.

Hall, B., Lerner, J., 2010. The financing of R\&D and innovation. In: Hall, B.H., Rosenberg, N. (Eds.), The Handbook of the Economics of Innovation, vol. I., pp. 609-639, Elsevier, Amsterdam, NL.

Heckman, J., Ichimura, H., Todd, P., 1997. Matching as an Econometric Evaluation Estimator: Evidence from Evaluating a Job Training Programme, Review of Economic Studies 64, 605-654.

Herrera, L., Nieto, M. 2008. The national innovation policy effect according to firm location. Technovation 28 (8), 540-550.

Herrera, L., Sánchez-González, G., 2013. Firm size and innovation policy. Internat. Small Bus. J. 31 (2), 137-155.

Hasebe, T., 2013. Copula-based maximum-likelihood estimation of sample-selection models. Stata J. 13, 547-573.

Herrmann, A., Tomczak, T., Befurt, R., 2006. Determinants of radical product innovations. European J. Innov. Manage. 9, 20-43.

Hewitt-Dundas, N., 2006. Resource and capability constraints to innovation in small and large plants. Small Bus. Econ. 26 (3), 257-277.

Hottenrott, H., Lopes-Bento, C., 2014. (International) R\&D collaboration and SMEs: The effectiveness of targeted public R\&D support schemes. Res. Policy 43(6), 1055-1066.

Kassicieh, K., Kirchhoff, B.A., McWhorter, P.J., Walsh, S.T., 2002. The Role of Small Firms in the Transfer of Disruptive Technologies. Technovation 22, 667-674.

Kaufmann, A., Tödtling, F., 2001. Science-industry interaction in the process of innovation: 
the importance of boundary-crossing between systems. Res. Policy 30(5), 791-804.

Keizer, J.A., Halman, J.I.M., 2007. Diagnosing risk in radical innovation projects. Res.

Technol. Manage. 50 (5), 30-37.

Koellinger, P., 2008. Why are some entrepreneurs more innovative than others? Small Bus. Econ. 31 (1), 21-37.

Lerner, J., 2009. Boulevard of Broken Dreams: Why Public Efforts to Boost Entrepreneurship and Venture Capital Have Failed and What to Do About It. Princeton University Press, Princeton, NJ.

Lhuillery, S., Pfister, E., 2009. R\&D cooperation and failures in innovation projects: empirical evidence from French CIS data. Res. Policy 38(1), 45-57.

López, A., 2008. Determinants for R\&D collaboration: evidence from manufacturing Spanish firms. Internat. J. Ind. Organ. 26 (1), 113-136.

Lundvall, B-Å., Nielsen, P., 2007. Knowledge management and innovation performance. Internat. J. Manpower 28 (3-4), 207-23.

Magro, E., Wilson, J.R., 2013. Complex innovation policy systems: Towards an evaluation mix. Res. Policy 42 (9), 1647-1656.

Marzucchi, A., Antonioli, D., Montresor, S., 2015. Industry-research co-operation within and across regional boundaries. What does innovation policy add? Papers Reg. Sci. 94(3), 500-524.

Matusiak M., Kleibrink A. (Eds.), 2018. Supporting an Innovation Agenda for the Western Balkans: Tools and Methodologies. Publications Office of the European Union, Luxembourg.

Millimet, D.L., Tchernis, R., 2009. On the Specification of Propensity Scores: with Applications to the Analysis of Trade Policies. J. Bus. Econ. Statist. 27 (3), 397-415.

Miotti, L., Sachwald, F., 2003. Co-operative R\&D: Why and with whom? An integrated framework of analysis. Res. Policy 32 (8), 1481-1500.

Miranda, A., Rabe-Hesketh, S., 2006. Maximum likelihood estimation of endogenous switching and sample selection models for binary, ordinal, and count variables. Stata J. $6(3), 285-308$.

Moncada-Paternò-Castello, P., Ciupagea, C., Smith, K., Tübke, A., Tubbs, M., 2010. Does Europe perform too little corporate R\&D? A comparison of EU and non-EU corporate R\&D performance. Res. Policy 39 (4), 523-536.

Nelson, R.R., 1959. The simple economics of basic scientific research. J. Political Econ. 67 (3), 297-306. 
Nooteboom, B. 2000. Learning and innovation in organizations and economies. Oxford University Press, Oxford.

OECD, 2006. Government R\&D Funding and Company Behaviour: Measuring Behavioural Additionality. OECD, Directorate for science, technology and industry, Committee for scientific and technological policy, OECD Publishing, Paris.

OECD, 2018. Competitiveness in South East Europe: A Policy Outlook, Competitiveness and Private Sector Development. OECD Publishing, Paris.

Oke, A., Burke, G., Myers, A., 2007. Innovation types and performance in growing UK SMEs. Internat. J. Operat. Prod. Manage. 27 (7), 735-753.

Ortega-Argilés, R., Vivarelli, M., Voigt, P., 2009. R\&D in SMEs: a paradox?. Small Bus. Econ. 33 (1), 3-11.

Oughton, C., Landabaso, M., Morgan, K., 2002. The Regional Innovation Paradox: Innovation Policy and Industrial Policy. J. Technol. Transfer 27, 97-110.

Paulson, A.S., O’Connor, G.C., Robeson, D., 2007. Evaluating radical innovation portfolios. Res.-Technol. Manage. 50 (5), 17-29.

Ponds, R., Van Oort, F., Frenken, K., 2007. The geographical and institutional proximity of research collaboration. Papers Reg. Sci. 86, 423-443.

Radas, S., Anic, I.D., Tafro, A., Wagner, V., 2015. The effects of public support schemes on small and medium enterprises. Technovation 38, 15-30.

Radicic, D., Douglas, D., Pugh, G., Jackson, I., 2019. Cooperation for innovation and its impact on technological and non-technological innovations: empirical evidence for European SMEs in traditional manufacturing industries. Internat. J. Inno. Manage. 23(5): 1950046.

Radicic, D., Pugh, G., 2016. R\&D Programmes, Policy Mix, and the 'European Paradox': Evidence from European SMEs. Sci. Public Policy 44(4), 497-512.

Radicic, D., Pugh, G., 2017. Performance Effects of External Search Strategies in European Small and Medium-Sized Enterprises. J. Small Bus. Manage. 55(S1), 76-114.

Radicic, D., Pugh, G., Hollanders, H., Wintjes, R., Fairburn, J., 2016. The impact of innovation support programs on small and medium enterprises innovation in traditional manufacturing industries: An evaluation for seven European Union regions. Environ. Planning C: Govern. Policy 34 (8), 1425-1452.

Radicic, D., Pugh, G., Douglas, D., 2018. Promoting cooperation in innovation ecosystems: evidence from European traditional manufacturing SMEs. Small Bus. Econ. https://doi.org/10.1007/s11187-018-0088-3 
Radosevic. S., 2013. Technology Upgrading and RTD Challenges in Western Balkan Region: Issues and Policy Options. In: Marinkovic, I., Dall, E. (Eds.). R\&D and Innovation in Western Balkans: Moving Towards 2020. WBC-INCO.NET c/o ZSI - Centre for Social Innovation, Austria.

Roper, S., Hewitt-Dundas, N., Love, J.H., 2004. An ex ante evaluation framework for the regional benefits of publicly supported R\&D projects. Res. Policy 33 (3), 487-509.

Scherer, F. M., Harhoff, D., 2000. Technology policy for a world of skew-distribution outcomes. Res. Policy 29, 559-566.

Schneider, C., Veugelers, R., 2010. On young highly innovative companies: why they matter and how (not) to policy support them. Ind. Corp. Change 19 (4), 969-1007.

Schumpeter, J.A., 1942. Capitalism, Socialism and Democracy. Harper, New York, NY.

Schwab, K., Sala-I-Martin, X. J., Samans, R. (eds.) 2017. The global competitiveness report 2017-2018. Geneva: World Economic Forum.

Smith, M.D., 2003. Modelling sample selection using Archimedean copulas. Economet. J. 6: 99-123.

Song, J., 2016. Innovation ecosystem: impact of interactive patterns, member location and member heterogeneity on cooperative innovation performance. Innov.: Manage., Policy Pract. 18 (1), 13-29.

Souchon, A.L., Dewsnap, B., Durden, G.R., Axinn, C.N., Holzmüller, H.H., 2015. Antecedents to export information generation: a cross-national study. Internat. Market. Rev. 32 (6), 732-761.

Spence, M., 1984. Cost reduction, competition and industry performance. Econometrica 54 (1), $101-121$.

Svarc. J., 2013. Comparative Analysis of the Innovation Capacities in the WBC with Emphasis on Joint Cooperation Needs in the Field of Innovation. In: Marinkovic, I. and Dall, E. (Eds.), R\&D and Innovation in Western Balkans: Moving Towards 2020. WBCINCO.NET c/o ZSI - Centre for Social Innovation, Austria.

Szczygielski, K., Grabowski, W., Pamukcu,M. T., Tandogan, V.S., 2017. Does government support for private innovation matter? Firm-level evidence from two catching-up countries. Res. Policy 46(1), 219-237.

Tether, B.S., 2002. Who cooperates for innovation, and why. An empirical analysis. Res. Policy 31, 947-967.

Tether, B.S., Tajar, A., 2008. Beyond industry-university links: sourcing knowledge for 
innovation from consultants, private research organisations and the public science-base. Res. Policy 37, 1079-1095.

Tracogna, A., 2016. Introduction - Closing the innovation gap in the Adriatic Region: the legacy of PACINNO. In: Cozza, C., Harirchi, G., Marković Čunko, A. (Eds.), Innovation in the Adriatic Region. Edizioni Universita di Trieste, Trieste.

Un, C. A., Cuervo-Cazurra, A., Asakawa, K., 2010. R\&D collaborations and product innovation. J. Prod. Inno. Manage. 27(5), 673-689.

UNESCO, 2016. UNESCO Science Report: toward 2030. UNESCO Publishing. Paris, France. van Praag, C. M., Versloot, P. H., 2008. What is the value of entrepreneurship? A review of recent research. Small Bus. Econ. 29, 351-382.

Wallsten, S.J., 2000. The effects of government-industry R\&D programs on private R\&D: the case of the Small Business Innovation Research program. RAND J. Econ. 31 (1), 82100.

Wernerfelt B., 1984. A resource-based view of the firm. Strategic Manage J. 5 (2), 171-180.

Veugelers, R., Cassiman, B. 1999. Make and buy in innovation strategies: evidence from Belgian manufacturing firms. Res. policy 28(1), 63-80.

World Bank, 2013. The Status of the Western Balkans Research and Innovation Sector: Report for the Western Balkans Regional R\&D Strategy for Innovation Technical Assistance Project. World Bank, Washington, DC. 


\section{Appendix}

Table A1. Descriptive statistics on innovative firms.

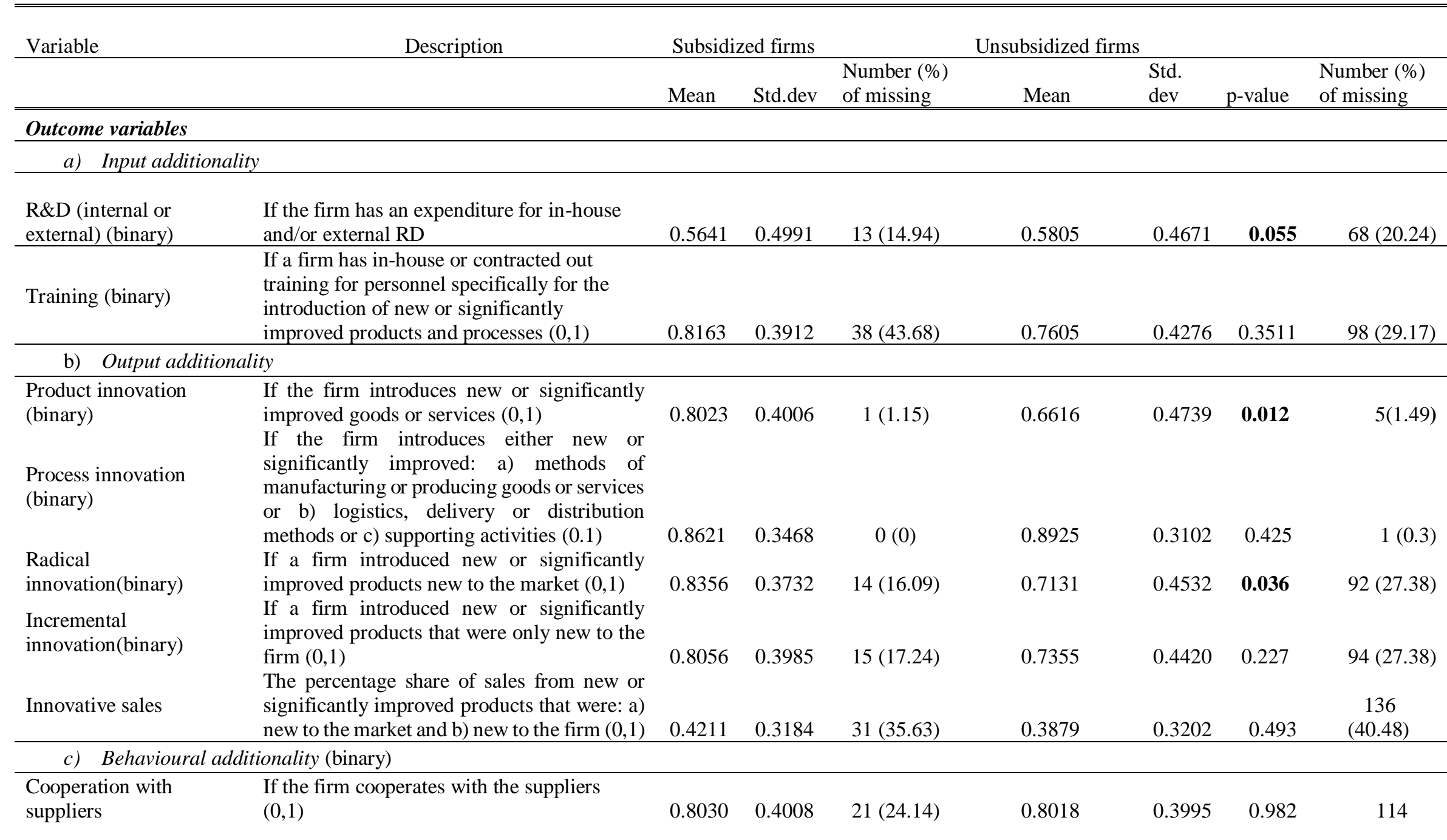




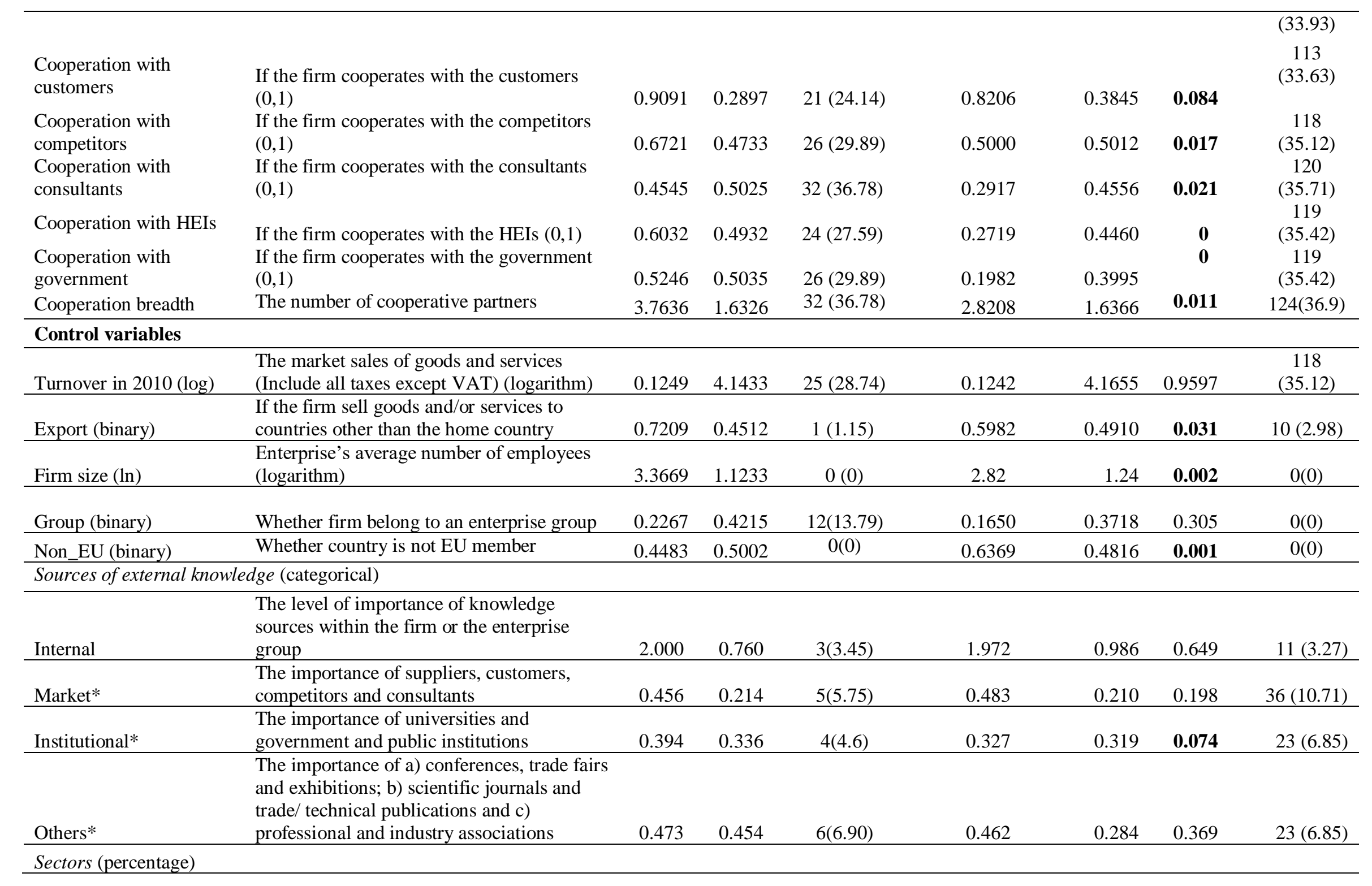


If the firm belongs to high-tech sector

according to

\begin{tabular}{|c|c|c|c|c|c|c|c|c|}
\hline High-tech manufacturing & NACE2 classification $(0,1)$ & 9.30 & 0.2922 & $1(1.15)$ & 5.39 & 0.2261 & 0.179 & $2(0.6)$ \\
\hline Low-tech manufacturing & $\begin{array}{l}\text { If the firm belongs to low-tech sector } \\
\text { according to NACE2 classification }(0,1)\end{array}$ & 22.09 & 0.4173 & $1(1.15)$ & 28.14 & 0.4504 & 0.599 & $2(0.6)$ \\
\hline $\begin{array}{l}\text { Knowledge intensive } \\
\text { service }\end{array}$ & $\begin{array}{l}\text { If the firm belongs to knowledge-intensive } \\
\text { service sector according to NACE2 } \\
\text { classification }(0,1)\end{array}$ & 44.29 & 0.4995 & $1(1.15)$ & 35.93 & 0.4805 & 0.159 & $2(0.6)$ \\
\hline $\begin{array}{l}\text { Less knowledge } \\
\text { intensive services }\end{array}$ & $\begin{array}{l}\text { If the firm belongs to less knowledge- } \\
\text { intensive service sector according to NACE2 } \\
\text { classification }(0,1)\end{array}$ & 10.47 & 0.3079 & $1(1.15)$ & 23.65 & 0.4256 & 0.007 & $2(0.6)$ \\
\hline $\begin{array}{l}\text { Other industries } \\
\text { (electricity, water supply } \\
\text { and construction) }\end{array}$ & $\begin{array}{l}\text { If the firm belongs to other sectors according } \\
\text { to NACE2 classification }(0,1)\end{array}$ & 13.95 & 0.3485 & $1(1.15)$ & 6.89 & 0.2536 & 0.034 & $2(0.6)$ \\
\hline
\end{tabular}

Note: t-test on mean differences is used for continuous variables while Chi2 test and Mann-Whitney tests are used for binary and ordinal variables, respectively.

* Following Cassiman and Veugelers (2002), the scores on each of these knowledge sources (ranging from 0 if a firm does not use a particular knowledge source to 3 for a high degree of importance) are summed up and the total score is rescaled to a number between 0 and 1 . 
Table A2. The correlation matrix.

\begin{tabular}{|c|c|c|c|c|c|c|c|c|c|}
\hline $\begin{array}{l}\text { Independent } \\
\text { variables }\end{array}$ & 1. & 2. & 3. & 4. & 5. & 6. & 7. & 8. & 9. \\
\hline $\begin{array}{l}\text { 1. Turnover } \\
\text { in } 2010\end{array}$ & 1.000 & & & & & & & & \\
\hline 2. Export & -0.003 & 1.000 & & & & & & & \\
\hline 3. Firm size & $0.167 * *$ & 0.087 & 1.000 & & & & & & \\
\hline 4. Group & 0.018 & 0.114 & $0.301 * * *$ & 1.000 & & & & & \\
\hline 5. Non-EU & $-0.136^{* *}$ & 0.066 & 0.024 & 0.003 & 1.000 & & & & \\
\hline $\begin{array}{l}\text { 6. Internal } \\
\text { sources }\end{array}$ & -0.103 & 0.079 & -0.021 & $0.168 * *$ & $0.305^{* * *}$ & 1.000 & & & \\
\hline $\begin{array}{l}\text { 7. Market } \\
\text { sources }\end{array}$ & 0.053 & -0.006 & -0.009 & $0.172 * *$ & $0.189 * * *$ & $0.369 * * *$ & 1.000 & & \\
\hline $\begin{array}{l}8 . \\
\text { Institutional } \\
\text { sources }\end{array}$ & 0.105 & 0.053 & -0.002 & $0.170 * *$ & $-0.128 *$ & 0.100 & $0.520 * * *$ & 1.000 & \\
\hline $\begin{array}{l}\text { 9. Other } \\
\text { sources }\end{array}$ & 0.089 & 0.038 & 0.039 & 0.083 & $0.143 * *$ & $0.257 * * *$ & $0.459 * * *$ & $0.376 * * *$ & 1.000 \\
\hline
\end{tabular}

Notes: $* * * * *, *$ correlation coefficients at the one, five or ten per cent level of significance. 
Table A3. Results of logit estimations. Dependent variable: participation in public support programmes in the period 2011-2013.

\begin{tabular}{|c|c|c|c|}
\hline Variables & $\begin{array}{c}\text { Model 1 } \\
\text { Input } \\
\text { additionality }\end{array}$ & $\begin{array}{c}\text { Model } 2 \\
\text { Output } \\
\text { additionality }\end{array}$ & $\begin{array}{c}\text { Model 3 } \\
\text { Behavioural } \\
\text { additionality }\end{array}$ \\
\hline & $\begin{array}{l}\text { Coef. } \\
\text { (SEs) }\end{array}$ & $\begin{array}{l}\text { Coef. } \\
\text { (SEs) }\end{array}$ & $\begin{array}{l}\text { Coef. } \\
\text { (SEs) }\end{array}$ \\
\hline Size & $\begin{array}{c}-0.003 \\
(0.004)\end{array}$ & $\begin{array}{c}0.002 \\
(0.001)\end{array}$ & $\begin{array}{c}0.003 \\
(0.002)\end{array}$ \\
\hline$R \& D$ & - & $\begin{array}{c}-0.212 \\
(0.411)\end{array}$ & $\begin{array}{c}-0.442 \\
(0.482)\end{array}$ \\
\hline Export & $\begin{array}{c}0.354 \\
(0.411)\end{array}$ & $\begin{array}{c}0.286 \\
(0.431)\end{array}$ & $\begin{array}{c}0.387 \\
(0.531)\end{array}$ \\
\hline Turnover & $\begin{array}{l}-0.007 \\
(0.057)\end{array}$ & $\begin{array}{c}-0.007 \\
(0.058)\end{array}$ & $\begin{array}{c}-0.028 \\
(0.068)\end{array}$ \\
\hline Group & $\begin{array}{l}-0.006 \\
(0.500)\end{array}$ & $\begin{array}{c}0.007 \\
(0.501)\end{array}$ & $\begin{array}{c}-0.242 \\
(0.600)\end{array}$ \\
\hline Cooperation & $\begin{array}{c}0.607 \\
(0.397)\end{array}$ & $\begin{array}{c}0.625 \\
(0.398)\end{array}$ & - \\
\hline Sources_internal & $\begin{array}{c}0.146 \\
(0.231)\end{array}$ & $\begin{array}{c}0.170 \\
(0.235)\end{array}$ & $\begin{array}{c}0.157 \\
(0.276)\end{array}$ \\
\hline Sources_market & $\begin{array}{l}-1.775 \\
(1.238)\end{array}$ & $\begin{array}{l}-1.784 \\
(1.239)\end{array}$ & $\begin{array}{l}-2.856^{*} \\
(1.463)\end{array}$ \\
\hline Sources_institutional & $\begin{array}{c}1.011 \\
(0.714)\end{array}$ & $\begin{array}{c}0.981 \\
(0.719)\end{array}$ & $\begin{array}{c}1.203 \\
(0.873) \\
\end{array}$ \\
\hline Sources_other & $\begin{array}{c}0.386 \\
(0.706)\end{array}$ & $\begin{array}{c}0.485 \\
(0.734)\end{array}$ & $\begin{array}{l}1.804 * * \\
(0.892)\end{array}$ \\
\hline Non-EU & $\begin{array}{c}-1.239 * * * \\
(0.425)\end{array}$ & $\begin{array}{c}-1.209 * * * \\
(0.430\end{array}$ & $\begin{array}{c}-1.352 * * * \\
(0.504)\end{array}$ \\
\hline Constant & $\begin{array}{l}-1.022 \\
(0.973)\end{array}$ & $\begin{array}{l}-0.959 \\
(0.982)\end{array}$ & $\begin{array}{c}-0.381 \\
(1.173)\end{array}$ \\
\hline Industry DVs & Included & Included & Included \\
\hline Pseudo $R^{2}$ & 0.113 & 0.114 & 0.141 \\
\hline$L R \chi^{2}$ & $25.15 * *$ & $25.41 * *$ & $24.82 * *$ \\
\hline No of obs. & 204 & 204 & 157 \\
\hline
\end{tabular}


Table A4. Estimated Average Treatment Effects on the Treated (ATT) excluding Slovenia.

\begin{tabular}{|c|c|c|c|c|}
\hline \multirow[t]{2}{*}{$\begin{array}{l}\text { Outcome } \\
\text { variables }\end{array}$} & NN matching & PSM & $\begin{array}{l}\text { IPTW } \\
\text { estimator }\end{array}$ & \multirow[t]{2}{*}{$\begin{array}{c}\text { Number of } \\
\text { obs. }\end{array}$} \\
\hline & $\begin{array}{c}\text { ATT } \\
\text { (Abadie and } \\
\text { Imbens SEs) }^{\mathrm{a}}\end{array}$ & $\begin{array}{c}\text { ATT } \\
\text { (Abadie and } \\
\text { Imbens SEs) }\end{array}$ & $\begin{array}{c}\text { ATT } \\
\text { (robust SEs) }\end{array}$ & \\
\hline \multicolumn{5}{|c|}{ Input additionality } \\
\hline $\begin{array}{l}\text { R\&D (internal or } \\
\text { external) }\end{array}$ & $\begin{array}{l}0.250 * * \\
(0.117)\end{array}$ & $\begin{array}{c}0.083 \\
(0.119)\end{array}$ & $\begin{array}{l}0.160 * * \\
(0.075)\end{array}$ & 159 \\
\hline Training $^{\mathrm{b}}$ & $\begin{array}{c}0.042 \\
(0.110)\end{array}$ & $\begin{array}{c}0.167 \\
(0.109) \\
\end{array}$ & $\begin{array}{l}0.170^{*} \\
(0.095)\end{array}$ & 147 \\
\hline \multicolumn{5}{|c|}{ Output additionality } \\
\hline $\begin{array}{l}\text { Product } \\
\text { innovation }\end{array}$ & $\begin{array}{c}0.042 \\
(0.099)\end{array}$ & $\begin{array}{c}0.000 \\
(0.124)\end{array}$ & $\begin{array}{l}-0.061 \\
(0.101)\end{array}$ & 158 \\
\hline $\begin{array}{l}\text { Process } \\
\text { innovation }\end{array}$ & $\begin{array}{l}-0.042 \\
(0.072)\end{array}$ & $\begin{array}{c}-0.083 * * \\
(0.039)\end{array}$ & $\begin{array}{l}-0.076 \\
(0.056)\end{array}$ & 159 \\
\hline $\begin{array}{l}\text { Radical } \\
\text { innovation }\end{array}$ & $\begin{array}{l}-0.050 \\
(0.118)\end{array}$ & $\begin{array}{c}-0.200^{* * * *} \\
(0.036)\end{array}$ & $\begin{array}{c}0.002 \\
(0.103)\end{array}$ & 131 \\
\hline $\begin{array}{l}\text { Incremental } \\
\text { innovation }\end{array}$ & $\begin{array}{c}0.000 \\
(0.129)\end{array}$ & $\begin{array}{c}-0.200 * * * \\
(0.073)\end{array}$ & $\begin{array}{l}-0.048 \\
(0.125)\end{array}$ & 131 \\
\hline Innovative sales & $\begin{array}{l}0.174 * \\
(0.089)\end{array}$ & $\begin{array}{l}-0.104 \\
(0.111)\end{array}$ & $\begin{array}{l}0.005 \\
(0.079)\end{array}$ & 125 \\
\hline \multicolumn{5}{|c|}{ Behavioural additionality } \\
\hline $\begin{array}{l}\text { Cooperation } \\
\text { with suppliers }\end{array}$ & $\begin{array}{l}-0.056 \\
(0.095)\end{array}$ & $\begin{array}{c}0.000 \\
(0.026)\end{array}$ & $\begin{array}{l}-0.033 \\
(0.052)\end{array}$ & 122 \\
\hline $\begin{array}{l}\text { Cooperation } \\
\text { with customers }\end{array}$ & $\begin{array}{c}0.111 \\
(0.087)\end{array}$ & $\begin{array}{l}-0.056 \\
(0.082)\end{array}$ & $\begin{array}{c}0.024 \\
(0.093)\end{array}$ & 122 \\
\hline $\begin{array}{l}\text { Cooperation } \\
\text { with competitors }\end{array}$ & $\begin{array}{c}0.333 * * \\
(0.164)\end{array}$ & $\begin{array}{r}0.333 * * \\
(0.141)\end{array}$ & $\begin{array}{c}0.289 * * * \\
(0.109)\end{array}$ & 122 \\
\hline $\begin{array}{l}\text { Cooperation } \\
\text { with consultants }\end{array}$ & $\begin{array}{l}0.389 * * \\
(0.166)\end{array}$ & $\begin{array}{c}0.000 \\
(0.095)\end{array}$ & $\begin{array}{l}0.196 \\
(0.125)\end{array}$ & 122 \\
\hline $\begin{array}{l}\text { Cooperation } \\
\text { with HEIs }\end{array}$ & $\begin{array}{l}0.222^{*} \\
(0.134)\end{array}$ & $\begin{array}{c}0.111 \\
(0.169)\end{array}$ & $\begin{array}{l}0.016 \\
(0.133)\end{array}$ & 122 \\
\hline $\begin{array}{l}\text { Cooperation } \\
\text { with government }\end{array}$ & $\begin{array}{c}0.611^{* * *} \\
(0.124)\end{array}$ & $\begin{array}{l}0.500 * * * \\
(0.145)\end{array}$ & $\begin{array}{c}0.445^{* * *} \\
(0.114)\end{array}$ & 122 \\
\hline $\begin{array}{l}\text { Cooperation } \\
\text { breadth }\end{array}$ & $\begin{array}{l}1.611 * * * \\
(0.474)\end{array}$ & $\begin{array}{l}0.889 * * \\
(0.405)\end{array}$ & $\begin{array}{l}0.948^{* *} \\
(0.381)\end{array}$ & 122 \\
\hline
\end{tabular}

Notes: ***,**, * ATT estimated at the one, five or ten per cent level of significance; ${ }^{a}$ Abadie and Imbens (2009) derived a method for variance estimation for $\mathrm{NN}$ matching which is applied in this study; ${ }^{\mathrm{b}}$ The outcome variable Training has all missing values for Slovenian firms, thus the results in this table are the same as in Table 2. 


\section{Figure A1. The overlap plots.}
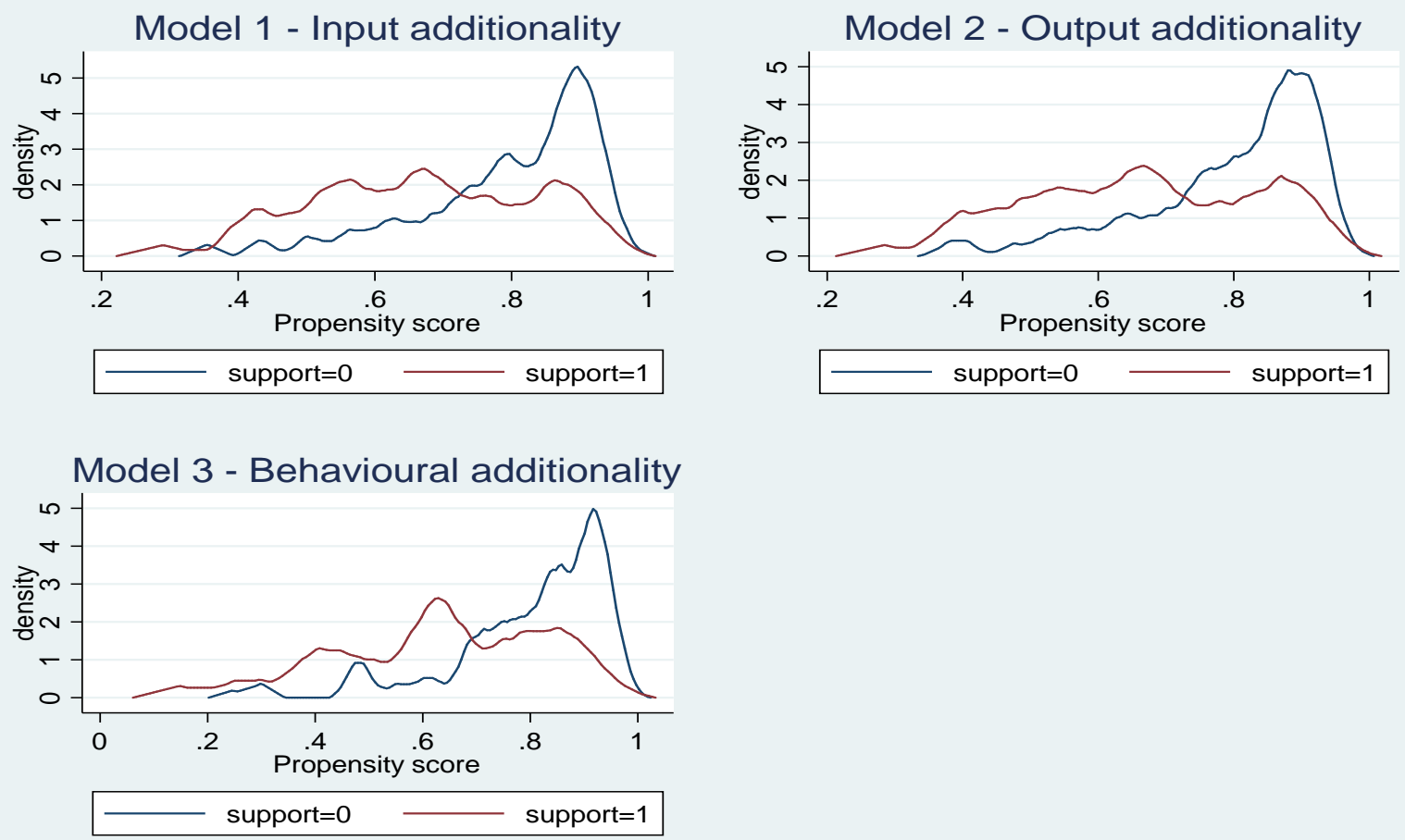